\title{
Ostensio ReGis: LA «REAL CORTINA» COMO ESPACIO Y MANIFESTACIÓN DEL PODER SOBERANO DE LOS Austrias ESPAÑOlES*
}

\author{
Jorge Fernández-Santos Ortiz-Iribas \\ Universitat Jaume I
}

\begin{abstract}
Mais nous fûmes bien aises de donner cette atteinte à l'étiquette; \& quand il y en auroit eu [de rideaux], nous ne nous en serions pas servis, la fantaisie de cacher un roi aimable au peuple me paroissant une des moins sages de Philippe II.
\end{abstract}

RESUMEN: Sin recurrir a tópicos como el de «monarquía oculta», nos proponemos interpretar aspectos clave del ceremonial de corte de los Austrias. La «cortina» o, más exactamente, el oratorio endoselado y cortinado del que servían los reyes en iglesias y capillas resulta difícilmente inteligible sin tener en cuenta precedentes bajomedievales franceses y una ontología de la realeza capaz, según demostrara E. H. Kantorowicz, de distinguir entre el ser humano mortal y el monarca como depositario de una dinastía imperecedera. Análogamente, el variado uso ceremonial de la «cortina» contribuía a deslindar las devociones privadas del hombre de las muestras públicas de piedad del soberano.

Palabras clave: España bajo los Austrias, Ceremonial de corte, Capilla Real, Los dos cuerpos del rey.

* Este trabajo se inserta dentro del proyecto de investigación RYC-2009-05346 cofinanciado por el Ministerio de Ciencia e Investigación y el Fondo Social Europeo. Una versión preliminar del mismo fue presentada en la Universitat Jaume I de Castellón el 9 de noviembre de 2010 durante el IX coloquio internacional del Grupo Europeo de Investigación POTESTAS convocado en esta ocasión bajo el título de Espacios de Poder / Räume der Macht. Agradezco las indicaciones y sugerencias, que se reflejan en nota, de los participantes Pedro Barceló Batiste, Juan José Ferrer Maestro, Christiane Kunst, Fernando López Sánchez y Víctor Manuel Mínguez Cornelles. Vaya asimismo un reconocimiento, especialmente grato, a Annemarie Jordan Gschwend por su oportuna orientación bibliográfica y comentarios. A la generosidad del director del Museo de Santa Cruz de Toledo, Alfonso Caballero Klink, debo la reproducción de la grisalla, recientemente restaurada, de Blas de Prado (fig. 10) y los datos referentes a la misma. 
ABSTRACT: When interpreting key features of the court ceremonial of Habsburg Spain the blanket concept of «hidden kingship» proves problematic. More specifically, the use of a curtained, canopied closet -a temporary oratory called the «cortina»- should be reconsidered in light of late mediaeval French precedents. In reality, a twobodied understanding of the royal office, as famously shown by E. H. Kantorowicz, grounded the subtle and complex ceremonial use of the «cortina», which was devised to differentiate the public displays of piety of the living representative of an undying dynasty from the private devotions of the flesh-and-blood man.

Keywords: Habsburg Spain, Court Ceremonial, Royal Chapel, The King's Two Bodies.

\section{¿UN CAPRICHO DE FELIPE II?}

Fn la carta de la que proviene la cita del encabezamiento, dirigida desde Earcelona el 16 de diciembre de 1701 a su confidente el marqués de Torcy, la princesa de los Ursinos daba cuenta de la reciente asistencia a misa de un jovencísimo Felipe V, acompañado de su adolescente esposa, María Luisa Gabriela de Saboya. ${ }^{1}$ Para gran alborozo de la atareada camarera mayor - y no sin los reparos del séquito de cortesanos castellanos - se había prescindido de las «cortinas» (o rideaux). De dar crédito a la Ursinos, el objeto de las mismas no sería otro que el de hurtar al pueblo la visión de sus reyes durante los actos litúrgicos. ${ }^{2}$ En realidad, la práctica ceremonial española consistía más bien en reservar para el rey (y para aquellos de estirpe regia que le acompañasen) un pequeño habitáculo de planta aproximadamente cuadrada, provisto de dosel y rodeado de cortinas, dentro del cual se disponían asientos y reclinatorios. La apariencia externa de lo que se venía en llamar abreviadamente la «cortina», pero que la tradición borgoñona describía más correctamente como oratorio portátil (oratoire), era bastante sencilla y muy cercana, como recuerdan las fuentes, a la de una «cama colgada», esto es, a un lecho bajo dosel con cortinas

1. Adrien-Maurice, duc de NoAilles / Claude-François-Xavier, abbé Millot, Mémoires politiques et militaires pour servir à l'histoire de Louis XIV et de Louis XV, Moutard, París, 1777, II, pp. 401-408.

2. Dentro de una larga sección dedicada al ceremonial español en el célebre Cérémonial diplomatique se refleja erróneamente la «Cortine» como «un Rideau qui est devant le Roi» - una simplificación, por lo demás típicamente dieciochesca y francesa, de las tradiciones de corte hispanas. Véase Jean DU MONT DE Carelskroon / Jean Rousset de Missy, Le Cérémonial diplomatique des cours de l'Europe, ou collection des actes, mémoires et relations qui concernent ses Dignitez, Titulatures, Honneurs E Prééminences, Chez Janssons à Waesberge, Wetstein \& Smith, \& Z. Chatelain / Chez P. De Hondt: la Veuve de Ch. Le Vier \& J. Ne'aulme, Ámsterdam / La Haya, 1739, II, liv. II, pp. 332-367 (pp. 334-335). 


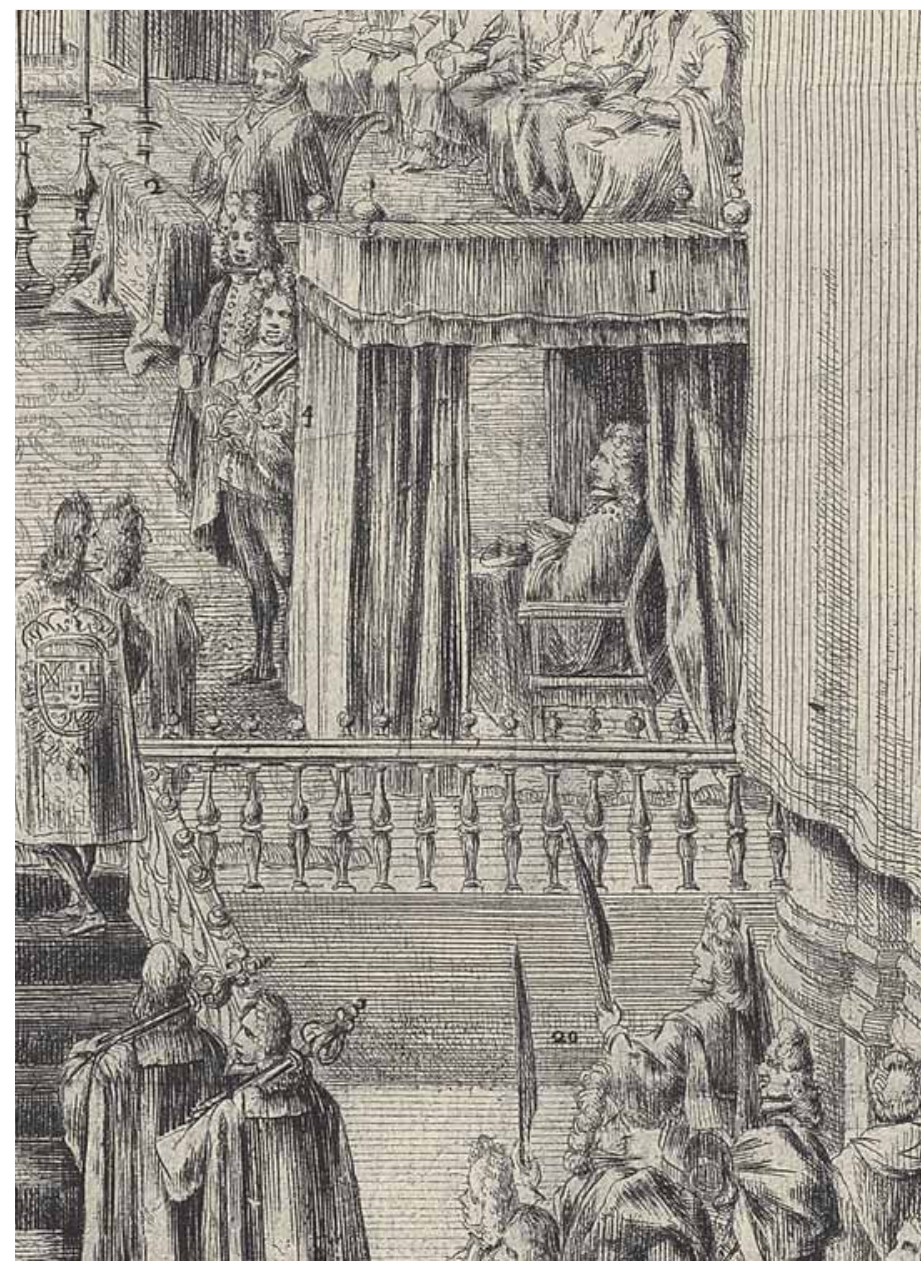

Fig. 1. Pedro de Araujo: Felipe V en su «Real Cortina» durante su jura como rey de Castilla y León en San Jerónimo El Real el 8 de mayo de 1701 (detalle de la fig. 5)

correderas alrededor [Fig. 1]. ${ }^{3}$ Aunque ya habrá ocasión de aclararlo con mayor detalle, no todas las cortinas de las que se componía la «cortina», ni mucho menos durante el transcurso íntegro de la celebración, permanecían corridas para proteger al rey de ojos curiosos. Nada de esto podía ignorar la camarera

3. Así la define el capellán Matteo Frasso en 1685: «Asiste SM. en la Capilla Real a los Oficios Divinos en parte distinta, y diferentemente adornada de todas las demas. Esta se llama Oratorio o Cortina. Oratorio porque es lugar en que SM. hace Oracion; y Cortina porque tiene forma de Cama colgada con su Cielo, y sus Cortinas pendientes: encierran dentro de si Sitial con una Silla. Componese el Sitial de diferentes, y varias partes, las quales juntas le dan en nombre de Sitial. Estas son una Tarima con un genuflexorio sobre que SM. se arrodilla, y la otra sobre el arrimadero donde pueda descansar los Brazos mientras esta arrodillado, y una silla en que se asienta; cubierto todo de un Tafetan muy dilatado que llega hasta el suelo cuyo propio nombre es terliz». RAH, ms. 9/708, ff. 147v-148r (\$10) [subrayado original de M. Frasso]. De la afinidad entre «cortina» y «cama colgada» se hace eco, entre otros, BHAM, ms. M/23, f. 31r. 
mayor, más aún si tenemos en cuenta que la familiaridad con la etiqueta española de la que era entonces joven princesa de Chalais se remontaba casi cuatro décadas. ${ }^{4}$ Ello no hace sino poner de relieve la intención peyorativa de sus comentarios de 1701, dirigidos contra un ceremonial palatino en cuya erradicación, más o menos progresiva, ella misma había de adquirir enorme protagonismo. No en vano el conde de Marsin había dictaminado que l'étiquette de los Austrias españoles, a la que asemeja a un monstruo, ${ }^{5}$ debía ser derribada sin nombrarla o, lo que es lo mismo, debía ser socavada y desautorizada en la práctica, sin menoscabo de una perpetuación puramente nominal de la misma que no perseguía otro objetivo que el de neutralizar la que se preveía cerrada oposición de los cortesanos españoles a su reforma. Nadie mejor que AnneMarie de La Trémoille, princesa de los Ursinos, para llevar a buen puerto esta estrategia de erosión de las complejas Etiquetas que Carlos II había legado a su heredero francés, Felipe V.

Bajo el deseo de los asesores franceses de Felipe $\mathrm{V}$ de minar la etiqueta española latían motivaciones de orden político y económico, algo a lo que la camarera mayor pretende quitar hierro rebajando las cuestiones de ceremonial a meras bagatelas. ${ }^{6}$ Que no era en absoluto así lo confirman sus acciones. Si en la reforma borbónica de las «plantas» de la corte, incluida la de la Real Capilla, se mezclan objetivos de centralización y racionalización del aparato administrativo de la monarquía, ${ }^{7}$ la disminución de sinecuras y gajes cortesanos era inseparable de la necesidad de saneamiento de las finanzas, agudizada si cabe por el alto coste de la guerra de Sucesión. A ello se unía un claro diagnóstico, seguramente avalado por la experiencia española de la propia Ursinos, residente en Madrid durante los inicios de la regencia de Mariana de Austria: ${ }^{8}$ la corte y la diplomacia francesas eran conscientes de que el acceso directo a la persona del monarca, regulado por un estricto y jerárquico ceremonial, se había convertido en una baza de primer orden para que la alta nobleza aumentase sus cotas de poder en Madrid. A nadie se le escapaba que, de seguirse al pie de la letra los dictados de la etiqueta, el nuevo rey, joven e

4. Aunque estemos lejos de conocer todos los detalles de la primera y larga estancia de Anne-Marie de La Trémoille en la corte española, sabemos que la aristócrata hubo de refugiarse en Madrid siguiendo a su esposo, Adrien-Blaise de Tayllerand-Périgord, príncipe de Chalais, exiliado de Francia para evitar el castigo que le impuso Luis XIII por su participación en el famoso duelo contra los hermanos de La Frette (1663). En la capital española permanece varios años hasta su salida rumbo a Italia. Habiéndose adelantado a su esposo, recibe en Roma la inesperada noticia de la muerte de este (1670) en la localidad veneciana de Mestre, de camino a la capital pontificia. En febrero de 1675, la aún joven viuda contrae en la Ciudad Eterna segundas nupcias con Flavio Orsini, v duque de Bracciano. La traducción al francés como «des Ursins» del ilustre apellido de su segundo marido - el príncipe y cabeza de familia «degli Orsini» - servirá años después de base para la hispanización de su título como «princesa de los Ursinos».

5. Noailles / Millot, Mémoires politiques, iI, p. 177.

6. «Je ne vous entretiens que de bagatelles». Ibid., p. 407.

7. Para una visión de conjunto, véase Juan Carlos SAAVEdRa ZAPATER, El primer reformismo borbónico en Palacio: La Capilla Real (1700-1750), UNED, Madrid, 2005.

8. Véase la nota 4 ut supra. El periodo entre 1665 y 1675 fue especialmente deslucido en lo tocante al ceremonial de capilla. Antonio Álvarez-Ossorio Alvariño, «La sacralización de la dinastía en el púlpito de la Real Capilla en tiempos de Carlos II», Criticón, 84-85 (2002), pp. 313-332 (p. 319). 
inexperto, perdería margen de maniobra para poner coto a los manejos de esas camarillas y facciones cortesanas que tanto habían pesado en el reinado de su tío-abuelo Carlos II. Como queda demostrado en un acertado estudio de Carlos Gómez-Centurión, ${ }^{9}$ el reglamento de «entradas» se convierte en el verdadero caballo de batalla de la desarticulación del ceremonial palatino de los Habsburgo en los inicios del reinado de Felipe V, sin que deba en absoluto sorprender el papel tutelar desarrollado por la princesa de los Ursinos en las reformas arquitectónicas del Alcázar madrileño, ${ }^{10}$ conducentes en gran medida a contrarrestar los privilegios de casi exclusividad de los grandes y titulados de la «primera esfera» en el servicio más íntimo e inmediato del monarca.

Dado este contexto y estas prioridades puede extrañar que la utilización de la tradicional «cortina» fuese objeto de atención de la Ursinos. Al fin y al cabo no afectaba directamente a cuestiones de proximidad al monarca durante sus actividades de despacho o en sus espacios domésticos o de asueto. Las razones que le llevan a trivializarla como un capricho de Felipe II merecen sin embargo ser tenidas en cuenta. Es más, en la misma misiva a Torcy, la aristócrata francesa apunta claramente al «fameux auteur de l'étiquette», a Felipe II, como blanco. ${ }^{11}$ Se unen por lo tanto dos cuestiones trascendentales: el grado en el que al retatarabuelo de Felipe $\mathrm{V}$ puede atribuirse la autoría de la etiqueta palatina en vigor en 1700 cuando tiene lugar el cambio dinástico y la naturaleza supuestamente caprichosa -0 , si se prefiere, arbitraria- de esa misma etiqueta. Aun sin profundizar demasiado en el tema, no ofrece ninguna duda que el uso de oratorios cortinados (portátiles o permanentes) no es una invención filipina y que, como su presencia en numerosas cortes bajomedievales deja bien claro, no se trataba de un capricho del Rey Prudente. Se hace evidente no tanto el desconocimiento de la Ursinos de los orígenes históricos y de los posibles significados de la práctica de velar y desvelar al monarca en determinados momentos de las celebraciones litúrgicas, como el marco referencial desde el que la francesa juzga, con no poca suficiencia, el ceremonial de los Austrias españoles. No es de extrañar que una cortesana de su rango, habituada a los fastos de Versalles, viera la «cortina» como algo trasnochado e inútil, como un vestigio de esa monarquía «oculta» y tiránica de Felipe II a la que desde algo más de una centuria la propaganda francesa contraponía la visibilidad y accesibilidad que, supuestamente, encarnaban

9. Carlos Gómez-Centurión Jiménez, «Etiqueta y ceremonial palatino durante el reinado de Felipe V: el reglamento de entradas de 1709 y el acceso a la persona del rey», Hispania, 56/3 (1996), núm. 194, pp. 965-1005.

10. Yves Bottineau, L'art de cour dans l'Espagne de Philippe V (1700-1746), Féret \& fils Éditeurs, Burdeos, 1962, pp. 268-280.

11. Noailles / Millot, Mémoires politiques, II, p. 408. Que la Ursinos se refiere sin duda a Felipe II lo entiende bien William Coxe, Memoirs of the Kings of Spain of the House of Bourbon, from the Accession of Philip V to the Death of Charles III (1700 to 1788), Longman, Hurst, Rees, Orme \& Brown, Londres, 1815, I, p. 168, que así lo aclara en una nota explicativa. 
sus propios monarcas. ${ }^{12}$ La línea argumental y propagandística en la que se fundamentaban los cambios introducidos en las ceremonias de corte en Madrid a partir de 1701 ponía el acento en que éstos habían sido diseñados para facilitar el acceso y la visión del monarca borbón, frente a la propensión de los Habsburgo a la reclusión y el ocultamiento. La ironía de todo ello estriba en que fue precisamente durante el reinado de Felipe V, nacido príncipe francés, cuando, una vez manifestada su inestabilidad mental, se asiste a estrafalarios episodios de monarquía «oculta» e incluso nocturna, con insólitos horarios de despacho trastornados al albur de las crisis de melancolía regia.

La contrapropaganda francesa, que no pocas veces bebía a su vez en fuentes españolas teñidas de hagiografía, ${ }^{13}$ había popularizado en el imaginario europeo un Felipe II recluido en lo más recóndito de El Escorial, perennemente oculto a unos súbditos cuyos destinos regía y de cuyas acciones se mantenía puntualmente informado. La parte de exageración y de distorsión en esta imagen, incluso si solo atendemos a la vejez y declive final del soberano, se hace palpable si se consulta la documentación que recapitula el ritmo prácticamente ininterrumpido de las ceremonias y jornadas reales en las últimas décadas del siglo xvi. Sin embargo, la extraordinaria fortuna de la misma, con ribetes de leyenda negra que llegan hasta la época romántica, ha pesado en la comprensión del personaje histórico y de sus acciones. Pesa a su vez en la interpretación moderna de la etiqueta palatina de los Austrias, hasta el punto de que el uso de la «cortina» ha sido visto como un síntoma más de ese supuesto estilo filipino de monarquía «oculta»..$^{14}$ La Ursinos era claramente de esa misma opinión, pero en ella contaba sobre todo la voluntad de liberarse de una etiqueta que entendía como un estorbo a su labor política. Con todo, en las palabras de la princesa, hay algo de verdad que quizás se le

12. Charles SABAtier, «Le roi caché et le roi Soleil: de la monarchie en Espagne et en France au milieu du XVII ${ }^{\mathrm{e}}$ siècle», en: C. Mazouer (ed.), L'âge d'or de l'influence espagnole. La France et l'Espagne à l'époque d'Anne d'Autriche 1615-1666, Éditions Inter Universitaires, Mont-de-Marsan, 1990, pp. 113-124. Sobre el supuesto encierro escurialense de Felipe II escribe André Duchesne, Les Antiquitez et recherches de la grandeur et maiesté des Roys de France, Jean Petit-Pas, París, 1609, pp. 465-466: «Et en ces derniers temps le Roy d'Espagne ayant acheué la conqueste de Portugal [...] s'enferma dans l'Escurial en intention de n'en sortir plus [...] Il tenait sa veue si rare aux Espagnols, que nul pour grand qu'il fust ne le voyait sans avoir longtemps poursuivy sa veue comme une extreme faveur». En la misma línea de exageración, Pierre Matthieu pretendía en 1607 que si un rey de Francia se retirase apenas un par de semanas a Saint-Germain de la vista de sus súbditos, al estilo de Felipe II, éstos quedarían desconsolados. Véase Pierre MatThIEU, Felipe II exterior e interior de una vida. Vida interior del Rey D. Felipe II atribuída comunmente al Abad de San Real, y por algunos al célebre español Antonio Pérez, su Secretario de Estado. Dala a la luz Don Antonio Valladares de Sotomayor, Andrés Ramírez, Madrid, 1788 (ed. facs. Sociedad de Fomento y Reconstrucción del Real Coliseo de Carlos III, Madrid, 1998), p. 47.

13. El renombrado cronista Baltasar Porreño, Dichos y hechos del Rey D. Felipe II, Editorial Saeta, Madrid, 1942, pp. 123-124, no tuvo empacho en escribir que Felipe II «se fué al Escurial con intento de no salir jamás dél, y como de atalaya, contemplar las ondas del orbe».

14. ¿Cómo entender de otro modo que L. Pfandl detecte en Felipe II una secreta complacencia hacia unos usos palatinos que despiertan «un subconsciente en él adormecido» o que pretenda que «en la escuela de este ceremonial» se acuña «más recia su dignidad nativa y su fría reserva»? Todo ello para rematar que «en el suelo español vienen a morir las risas sonoras de Borgoña» como «efecto y poso de un alma colectiva española» que el propio rey contribuye «mucho a profundizar». Ludwig PfandL, Felipe II. Bosquejo de una vida y de una época, Cultura Española, Madrid, 1942, pp. 166-167. 


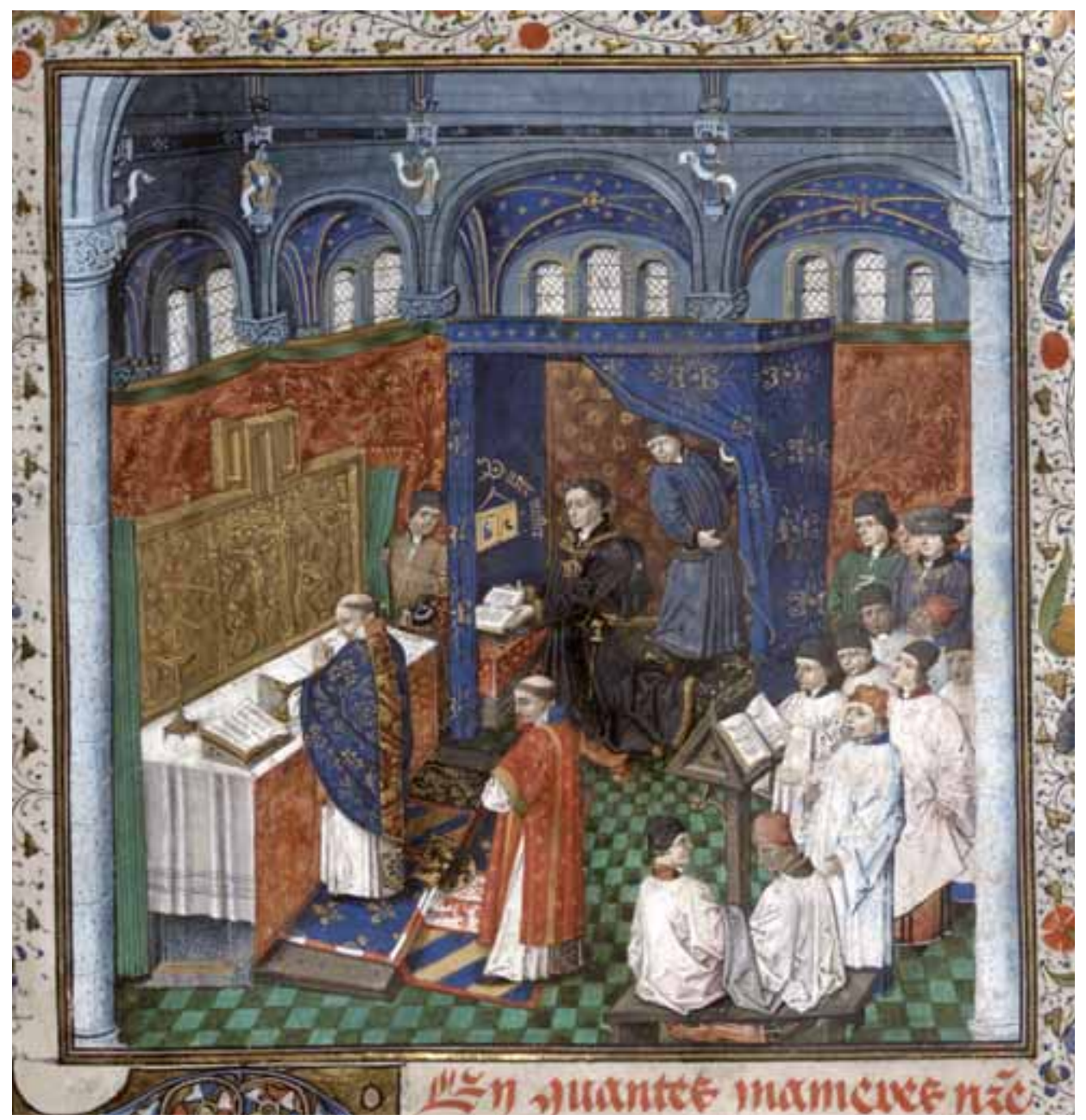

Fig. 2. Jean Le TAVernier (?): Felipe El Bueno, duque de Borgoña, asiste a misa, detalle del códice Traité sur l'oraison dominicale (p.q. 1457). Pergamino miniado, 397 x 287 mm. Bibliothèque royale de Belgique, Bruselas, ms. 9092, f. 9r

escapase a ella misma. Si bien es cierto que la «cortina» no se origina con Felipe II, como pretende la camarera mayor, no cabe negar que el modo en que este rey entiende y escenifica su potestad regia imprime un peculiar sello al ceremonial que hereda de sus mayores castellano-aragoneses y flamencoborgoñones. Lo paradójico -y la cortesana francesa no parece ni siquiera intuirlo- es que esa «cortina» que ridiculiza como caprichosa ocultación de un agraciado soberano (Felipe $\mathrm{V}$ en el apogeo de su juventud) era una de las manifestaciones ceremoniales más claras de la perennitas de la monarquía tal y como la entendían los reyes franceses durante la Baja Edad Media. Solo con posterioridad, y a través de una rama de la estirpe reinante de los Valois, esta práctica francesa arraiga entre los duques de Borgoña. Más tarde, la heredera 
de Carlos El Temerario, última Valois propietaria de los estados flamencoborgoñones, transmitirá a su vez estos usos y ceremonias a su hijo Felipe I El Hermoso y a su nieto el emperador Carlos V. Esa «cortina» utilizada por los Austrias españoles y cuya invención Madame des Ursins atribuye a Felipe II tenía en realidad como ascendencia histórica principal, aunque no única, la utilización en espacios sacros por parte de los reyes de Francia y de sus descendientes directos de nichos u oratorios con cortinas [Fig. 2 y 3]. Era por lo tanto una ceremonia antes francesa que española por más que, aparentemente y como consecuencia de su falta de vigencia entre los últimos Valois y sus sucesores Borbones, se hubiese, aparentemente, perdido la memoria de ello en la corte gala. ${ }^{15}$

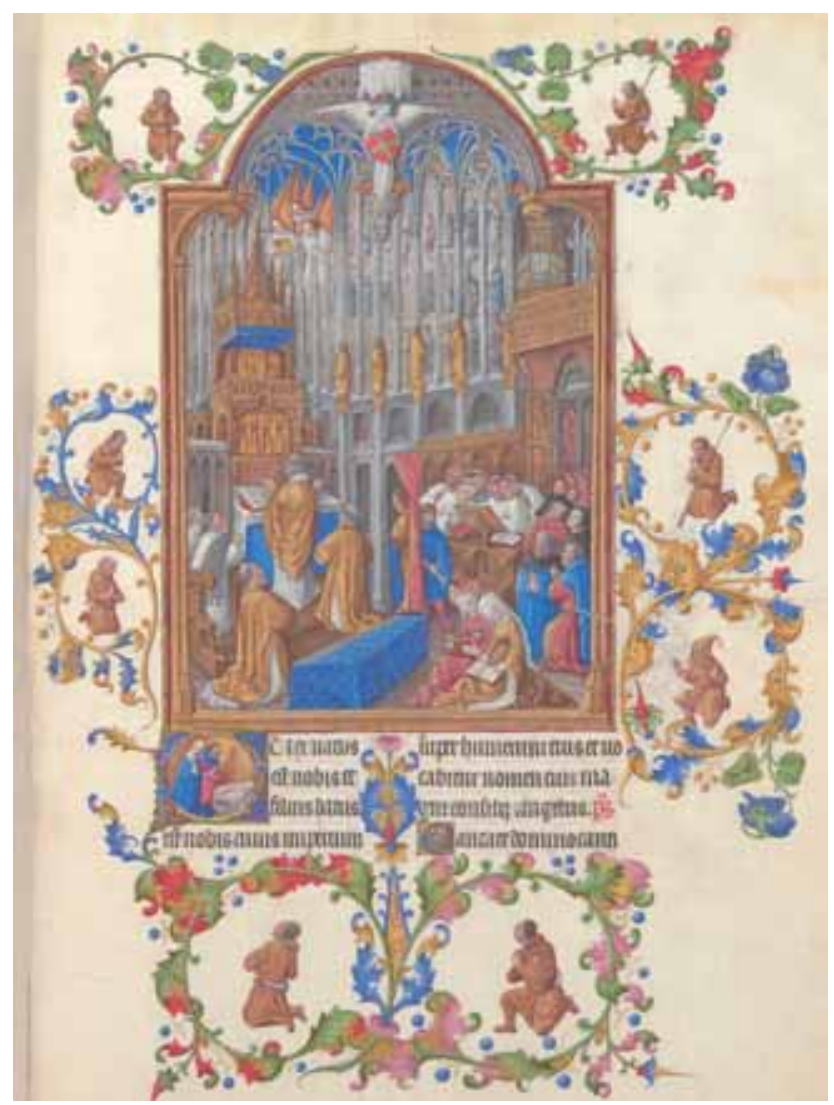

Fig. 3. Herman, Paul y Johan Limburg: La Messe de Noël (Juan I, duque de Berry, asiste a la misa de Navidad) del códice Les Très Riches Heures du duc de Berry (1410-16, completado en 1485-89). Pergamino miniado, 290 x 210 mm. Musée Condé, Château de Chantilly, ms. 65, f. 158r @ Réunion des Musées Nationaux, París

15. Así parece desprenderse de la perplejidad que delata el abad Bertaut en 1668 al describir la «cortina» que usan los monarcas españoles: «à un des costez de l'Église, sous una cortina, qui est un pavillon avec des rideaux, et un ciel qui y est ordinairement, et je l'ay toujours veû du costé de l'Evangile, de façon qu'on ne le voit point» (citado por SABATIER, Le roi caché, p. 122). 


\section{ANTIGÜEDAD, AUNQUE CONFUSA, LLEVA CONSIGO VENERACIÓN}

La raigambre histórica de los rituales en los que se vela y desvela mediante cortinajes la presencia del soberano parece perderse en la noche de los tiempos. La Persia sasánida constituye un hito fundamental de un tipo de rito que, en cronologías y geografías extraordinariamente amplias, se perpetúa en la medida en que se pretende revestir a la presencia del gobernante supremo de una aureola teofánica. ${ }^{16}$ Pero es precisamente este carácter directamente sacralizante el que tiene difícil cabida en el mundo cristiano. Como recuerda pertinentemente Marcel Gauchet, la divinización de los soberanos queda descartada en un sentido estructural intrínseco por la religión cristiana. ${ }^{17}$ No quiere ello decir que no se articulen maneras de exaltar a los monarcas y de resaltar escenográficamente su presencia en actos litúrgicos. Los ámbitos y las ceremonias mismas, sin embargo, no pueden soslayar la naturaleza mortal del soberano y su pertenencia a un cuerpo místico en el que se hace real la esperanza de salvación eterna de todos los fieles, sin distinción alguna. El complejo caso de la prokypsis bizantina ${ }^{18}$ cuidadosamente orquestada para hacer patente al emperador ante el pueblo en la kathisma del hipódromo, debe entenderse dentro de las particularidades de un ceremonial -por lo demás sujeto a variaciones muy considerables a lo largo de la historia- en el que el culto imperial romano permanece, a pesar de la cristianización, de algún modo latente. Por lo que se refiere a Hagia Sophia, está ampliamente documentado el uso de un metatorion: ${ }^{19}$ en este espacio acotado, a mitad de camino entre palco imperial y oratorio, el emperador disponía de un trono

16. Arthur Christensen, L'Iran sous les Sassanides, Levin \& Munksgaard - Ejnar Munksgaard Librairie Orientaliste - Paul Geuthner, Copenhague / París, 1936, pp. 390-399. Agradezco las indicaciones de Fernando López Sánchez relativas al ceremonial sasánida.

17. Marcel Gauchet, «Des deux corps du roi au pouvoir sans corps. Christianisme et politique (1)», Le débat, núm. 14 ( julio-agosto 1981), pp. 137-157 (p. 151): «Si à l'image du Christ qu'on le voie, dès lors, il est un lieu suprême, une fonction ultime que le roi jamais ne pourra absolument occuper ou remplir. Pas de doute qu'on a là un des éléments dynamiques fondamentaux de l'histoire du pouvoir en Occident: d'emblée, une certaine prétention à la classique divinisation despotique s'en est trouvée structurellement interdite».

18. Bizancio hereda de la Roma del Bajo Imperio la visión teofánica del emperador, a partir de la cual surgirá la ceremonia de la prokypsis. André GrABAR, «Pseudo-Codinos et les cérémonies de la cour

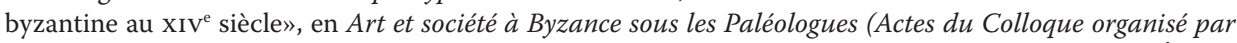
l'association internationale des études byzantines à Venise en septembre 1968), Institut Hellénique d'Études Byzantines et Post-Byzantines de Venise, Venecia, 1971, pp. 193-221 (pp. 201-211). Véase asimismo los pasajes pertinentes del Tratado de los oficios (1347-68) del llamado PSEUDO-Kodinos: J. Verpeaux (ed. y trad.), Traité des offices, Éditions du C.N.R.S., París, 1966, IV, pp. 198 y 203-204 y viI, p. 269. Como me indica oportunamente Juan José Ferrer, para el reinado de Justiniano resulta inexcusable la referencia a los escritos de Procopio de Cesárea.

19. El metatorion en Santa Sofía delimitaba un espacio en el que el emperador, sentado en su trono, permanecía aislado del público asistente. Aunando características del palco imperial y de los oratorios privados, se accedía a él privadamente a través de un recibidor en el ángulo sudeste de la nave basilical. Rowland J. Mainstone, Hagia Sophia: Architecture, Structure and Liturgy of Justinian's Great Church, Thames \& Hudson, Londres, 1988, pp. 223-226. George P. MAjEsKA, «The Emperor in His Church: Imperial Ritual in the Church of St. Sophia», en: H. Maguire (ed.), Byzantine Court Culture from 829 to 1204, Dumbarton Oaks Research Library and Collection / Harvard University Press, Washington D.C. / Cambridge, Massachusetts, 1997, p. 6. 
en el que recogerse resguardado de miradas indiscretas. A pesar de que se ha destacado la importancia de precedentes iraníes y bizantinos en la ocultación del califa detrás de una cortina $($ sitr $),{ }^{20}$ nada autoriza a ver en el uso de la «cortina» en la España de los Austrias una reminiscencia islámica, ${ }^{21}$ como sí parecen serlo en cambio las almohadas para el asiento de las damas. Los estrechos vínculos entre Bizancio y la Francia capetina pueden haber jugado un papel en la difusión de cortinas para ocultar y desvelar a los soberanos en el ámbito sacro. ${ }^{22}$ En cualquier caso, la costumbre regia y principesca de servirse de oratorios con cortinas, tanto permanentes como portátiles, en las iglesias y las capillas, especialmente en aquellas bajo su directo patronazgo, no era privativa de la corte francesa. Su presencia puede de hecho documentarse en varias cortes bajomedievales como la portuguesa ${ }^{23}$ la inglesa y la escocesa. ${ }^{24}$

20. Según Armand ABel, Le Khalife, presence sacrée, Larose, París, 1957, p. 33, la costumbre islámica de esconder al califa detrás de una cortina deriva de precedentes iraníes y bizantinos. La cortina o sitr, de cuya apertura y cierre se encargaba el sahib as-sitr, permitía la ocultación y posterior aparición del califa durante las audiencias. Dominique Sourdel, «Questions de cérémonial 'abbaside», Revue des Études Islamiques, 28 (1960), pp. 121-148 (p. 146).

21. Importa subrayar que los califas omeyas en España no se sirvieron del sitr en las audiencias. Ello hace aún más improbable establecer una filiación islámica convincente para el uso bajomedieval de cortinas en el ceremonial de capilla catalano-aragonés. Miquel BARCELó Perelló, «El califa patente: el ceremonial omeya de Córdoba o la escenificación del poder», en El sol que salió por occidente (Estudios sobre el estado omeya en al-Andalus), Universidad de Jaén, Jaén, 1977, pp. 137-162 (p. 142).

22. Las fluidas relaciones entre Bizancio y la Francia capetina son muy notorias. Recuérdese, por ejemplo, el doble matrimonio en 1180 entre María Commenos y Rainiero de Monferrato y entre Alexios Commenos e Inés de Francia. Michael Jeffreys, «The Vernacular eisithrioi for Agnes of France», en: E. y M. Jeffreys y A. Moffatt (ed.), Byzantine Papers: Proceedings of the First Australian Byzantine Studies Conference (Canberra, 17-19 May 1978), Humanities Research Centre, Australian National University, Canberra, 1981, pp. 101-115 (p. 107). Como es bien sabido, en la cuarta década del siglo xıI las reliquias de la Pasión de Cristo existentes en Constantinopla fueron adquiridas para la Sainte-Chapelle de París. William Chester Jordan, «Liturgical and Ceremonial Cloths: Neglected Evidence of Medieval Political Theology», Revue des archéologues et historiens d'art de Louvain, 12 (1979), pp. 104-119 (p. 109).

23. Aparentemente, la cortina en uso en la capilla de los reyes portugueses carecía de «cielo» o dosel. Así se desprende de la ilustración que aparece en el f. 35 del célebre Livro Vermelho de Alfonso v. Rita Costa Gomes, A Corte dos Reis de Portugal no final da Idade Média, Difel Difusão Editorial, Linda-a-Velha, 1995, p. 316. ID. «The Royal Chapel in Iberia: Models, Contacts, and Influences», The Medieval History Journal, 12/1 (2009), pp. 77-111 (pp. 94-107). Véase asimismo Annemarie JorDAN GsCHwend, «La Capela Real del Palazzo Reale di Lisbona: Politica, Dottrina, Ceremoniale e Committenza Religiosa alla Corte di Giovanni III e Caterina d'Austria» en: G. Bertini (ed.), Maria di Portogallo, sposa di Alessandro Farnese. Principessa di Parma e Piacenza dal 1565 al 1577, Ducati, Parma, 2001, pp. 27-81.

24. En el extremo oeste de la Royal Chapel se situaba una galería alta o «royal closet» reservada para el monarca. John Adamson hace notar que la sacralidad del rey era puesta de relieve, aún más si cabe, mediante la utilización de un cubículo cortinado a modo de tabernáculo que recibía el nombre de «traverse». A ello que añade algo no menos significativo, dada la palmaria semejanza con la «cortina» hispano-borgoñona: tanto antes como después de la reforma anglicana se disponía asimismo de una traverse desmontable que se alzaba junto al altar de la capilla. John ADAMSON, «The Tudor and Stuart Court 1509-1714» en: J. Adamson (ed.), The Princely Courts of Europe: Ritual, Politics and Culture under the Ancien Régime 15001750, Weidenfeld \& Nicolson, Londres, 1999, pp. 98-105 (pp. 102-104). El royal closet y la traverse de uso temporal corresponderían mutatis mutandis al cancel y a la "cortina» de la Real Capilla española. No se puede, sin embargo, avalar la hipótesis de una derivación hispana de la traverse inglesa -cuyo uso es anterior a la dinastía Tudor- sino más bien la de una común ascendencia francesa de ambas. Véase al respecto dos importantes fuentes de mediados del siglo xv: la Founder's Charter del King's College de Cambridge (16 de marzo de 1446) en la que aparece Enrique VI en oración dentro de una traverse y lo referido en William SAY / W. Ullman (ed.), Liber Regie Capelle: A Manuscript in the Biblioteca Publica, Evora, Henry Bradshaw Society / Cambridge University Press, Londres / Cambridge, 1961, IX, p. 64. Dos miniaturas de las Hours 
Sin que sea fácil -y tampoco es el objetivo que persiguen estas páginasdar cuenta de los intercambios que determinaron la difusión europea de este tipo de ceremonia, en la que bien pudieran cruzarse y solaparse varias ascendencias y modelos, no resulta, sin embargo, arriesgado hacer hincapié en unos referentes inmediatos y claros para la corte madrileña de los Habsburgo. Son, como se dijo anteriormente, fundamentalmente franceses o, tomando prestado el término de Jeroen Duindam, ligados a una tradición sincrética franco-borgoñona-hispánica. ${ }^{25}$

Es especialmente significativo que sea el erudito capellán borgoñón Jules Chifflet el que apunte en la dirección correcta, aclarando los precisos orígenes históricos del uso de los oratorios cortinados y endoselados en la cultura palatina de los duques Valois de Borgoña. ${ }^{26}$ Como explica Chifflet y corroboran varias fuentes, incluyendo los Libros de horas miniados, ${ }^{27}$ Felipe El Bueno, duque de Borgoña, asistía a misa en un cubículo que es, efectivamente, en todo similar al que usarán más tarde sus descendientes directos, los Austrias [Fig. 2]. De hecho, la utilización por parte de los duques de Borgoña de un cubículo cortinado está indisolublemente ligada a la existencia de oratorios, en principio fijos, dotados de cortinas [Fig. 3] para uso de los monarcas franceses en lugares de culto asociados a ellos como la emblemática SainteChapelle parisina. ${ }^{28}$ Se documenta asimismo su existencia, aunque no se hayan conservado físicamente, en la Sainte-Chapelle de Bourges, la Chartreuse de Champmol y la Sainte-Chapelle de Dijon, lugares privilegiados de la piedad ducal borgoñona. ${ }^{29}$ Toda estas capillas de príncipes borgoñones de sangre

of King James of Scotland, de principios del siglo XVI, demuestran que la traverse formaba también parte del ceremonial de capilla de los Estuardo, algo que podría estar relacionado con el origen inglés de la reina Margarita de Escocia, hermana de Enrique VIII Tudor.

25. Jeroen DUINDAM, «El legado borgoñón en la vida cortesana de los Habsburgo austríacos» en: K. De Jonge, B. J. García García y A. Esteban Estríngana, El Legado de Borgoña. Fiesta y Ceremonia Cortesana en la Europa de los Austrias (1454-1648), Fundación Carlos de Amberes / Marcial Pons Historia, Madrid, 2010, pp. 35-58 (p. 42).

26. Jules CHifflet, Aula Sacra Principum Belgii, sive Commentarius Historicus de Capellce Regice in Belgio Principijs, Ministris, Ritibus atque vniuerso Apparatu, Officina Plantiniana Balthasaris Moreti, Amberes, 1650, cap. IV, pp. 21-24 y cap. viI, pp. 63-68.

27. Emilio Ros-FÁbregAs, «Música y músicos 'extranjeros' en la España del siglo xvi», en: J. J. Carreras López y B. J. García García (ed.), La Capilla Real de los Austrias. Música y ritual de corte en la Europa moderna, Fundación Carlos de Amberes / Fernando Villaverde Ediciones, Madrid, 2001, pp. 101-126 (p. 125, núm. 3, repr. Bibliothèque Royale de Belgique, Bruselas, ms. 9126, f. 2r).

28. Daniel H. WeIss, Art and Crusade in the Age of Saint-Louis, Cambridge University Press, Cambridge, 1998, pp. 18-19 y plate II.

29. Christian DE MÉRINdol, «Art, spiritualité et politique: Philippe le Hardi et la Chartreuse de

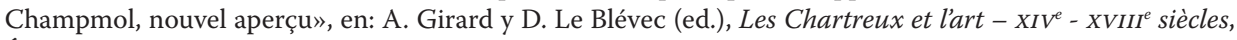
Éditions du Cerf, París, 1989, pp. 98-99, 104 y 107. Kathleen Morand, Claus Sluter Artist at the Court of Burgundy, Harvey Miller Publishers, Londres, 1991, pp. 320-330. Pierre QuARrÉ, La Sainte-Chapelle de Dijon. Siège de l'Ordre de la Toison d'Or, Musée de Dijon, Dijon, 1962, p. 8. Jeffrey Chipps SmiтH, «The Chartreuse de Champmol in 1486: The Earliest Visitor's Account», Gazette des Beaux-Arts, 106 (1985), núm. 1398-1399, pp. 1-6 (p. 4). Pierre-Jean TrombetтA, «Bourges: le palais ducal et la Sainte Chapelle», Archéologia, núm. 134 (septiembre 1979), pp. 16-25 (pp. 17-18 y 25). Georg ZEMAN, «Jean de Berry und die Sainte-Chapelle in Bourges», Wiener Jahrbuch für Kunstgeschichte, 49 (1996), pp. 235-273 y 357-362 (p. 357). 
Valois se habían acogido explícitamente al prototipo de París («ad instar capella regii parisiensis») al igual que ocurriera con, entre otras, la capilla del Château du Vivier, la del Château de Vincennes y la del Palais de Riom. ${ }^{30}$ Estos ejemplos de los siglos XIII y XIV entre monarcas y príncipes de estirpe real francesa ponen de manifiesto que se trataba de una práctica consolidada. El precioso testimonio de Chifflet así lo aclara en referencia al encuentro de 1378 entre el emperador Carlos IV y el rey de Francia Carlos V. ${ }^{31}$ La crónica de la presencia de ambos monarcas en la Sainte-Chapelle para asistir a la ostensio reliquiarum, a la ostensión de las reliquias de la Pasión de Cristo en ella conservadas, generó un pequeño incidente de protocolo. El emperador, obviamente no familiarizado con este uso, rechazó las cortinas, motivando que el rey francés optase por hacer lo mismo en deferencia a su huésped. Queda claro que la práctica de velar parcialmente la presencia del rey orante en misa no se contaba entre los usos comunes en la corte del Sacro Romano Imperio en el siglo XIV (como no lo será tampoco posteriormente) ${ }^{32} \mathrm{y}$, por el contrario, formaba parte de las ceremonias consuetudinarias de la corte francesa.

La supuestamente opresiva etiqueta borgoñona que atenazó a los cinco soberanos de la casa de Austria que se sucedieron en el trono de España quizás no lo fuese en el grado sumo que usualmente se supone, ni deba entenderse en modo alguno como la importación unilateral de usos extraños a la corte castellana. En cualquier caso, el hecho más llamativo, la adopción en 1548 por parte de Felipe II, entonces tan solo un príncipe, de la etiqueta borgoñona marca, aparentemente, un punto de inflexión, aunque como precisa con razón Raymond Fagel, ${ }^{33}$ el periodo de convivencia entre usos ceremoniales hispánicos y borgoñones ha de remontarse a dos fechas claves, correspondientes a las llegadas a Castilla de Felipe I El Hermoso en 1501 y de su hijo Carlos V en 1517. Como sabemos, el futuro Felipe II se embarcaría, casi inmediatamente después de la reorganización de su casa al estilo de Borgoña, en el llamado Felicissimo Viaje europeo de 1549-1552. ${ }^{34}$ Resulta lógico pensar que Carlos V

30. Al igual que para los ejemplos borgoñones anteriormente citados, la Sainte-Chapelle de París sirve de modelo tipológico de las capillas palatinas de Bourbon-l’Archambault para Luis de Borbón (c. 1320), del Château du Vivier para el futuro Carlos V de Francia (c. 1352), del Château de Vincennes (empezada en 1379) y del Palais de Riom (finalizada en 1386) para el duque de Berry.

31. Chifflet, Aula Sacra, cap. IV, pp. 21-22 (\$I).

32. No ofrece dudas el hecho de que los Austrias españoles heredaron la práctica ceremonial de la «cortina» de sus antepasados borgoñones de sangre Valois y no de sus ancestros germanos de estirpe habsbúrgica. A modo de ejemplo, un cortesano dejaba constancia el 17 de septiembre de 1503 de la ausencia de «oratoire» al uso de Borgoña en Yzebrouch (Innsbruck) para uso de su señor Felipe I El Hermoso debido a que «les Allemans n'en y mettent point». Louis-Prosper GACHARD, Collection des voyages des souverains des Pays-Bas, F. Hayez, Bruselas, 1874-82, I, p. 313. Véanse asimismo las precisiones de DuindAM, Legado borgoñón, p. 42, sobre las significativas diferencias entre los dos principales ceremoniales palatinos de la dinastía Habsburgo, el vienés y el madrileño de ascendiente franco-borgoñón.

33. Raymond FAgEL, «La cultura de corte en España y los Países Bajos alrededor de 1500», La Torre de los Lujanes, 44 (2001), pp. 27-41 (pp. 28-29).

34. Juan Calvete de Estrella / P. Cuenca Muñoz (ed.), El Felicísimo Viaje del Muy Alto y Muy Poderoso Príncipe Don Phelippe, Sociedad Estatal para la Conmemoración de los Centenarios de Felipe II y Carlos V, 2001 (publ. orig. Martín Nucio, Amberes, 1552). 
desease que la casa de su hijo quedase estructurada de acuerdo al entonces más prestigioso ceremonial de corte europeo, el borgoñón, en el preciso momento en el que este se había de dirigir, además de a Italia y Alemania, a los estados patrimoniales flamenco-borgoñones en los que habría de reinar un día. Como quedó dicho, entre otros rasgos distintivos de la tradición borgoñona, los duques de estirpe Valois que se extinguen en 1477 a la muerte de Carlos El Temerario, mantenían un tipo de oratorio protegido por cortinas, llamado precisamente así, oratoire, desde el cual asistían a las ceremonias religiosas. Entre los oficios del llamado sumiller de cortina (o de oratorio) estaba el de correr y descorrer las cortinas en momento precisos de la liturgia. Nótese además que la propia nomenclatura palatina deja adivinar sin dificultad el origen borgoñón de estos «sumilleres» o sommeliers d'oratoire, un oficio que las cortes castellanas no lograron eliminar ante la negativa de Felipe II. ${ }^{35}$ En el siglo XVII, se detecta entre los capellanes reales de los Austrias una clara conciencia de que los usos de la Real Capilla española y muy especialmente la «cortina» respondían, en lo esencial, a precedentes borgoñones. ${ }^{36} \mathrm{~A}$ pesar de la manifiesta voluntad de «historiar» la Real Capilla a través de las sucesivas compilaciones, tanto manuscritas como impresas, no está de más preguntarse por lo fiables (o poco fiables) que estas pueden resultar en la medida que transmiten una impresión de estatismo en los usos. Los propios historiadores palatinos de época de los Austrias menores reconocen en no pocos casos lo complicado que resulta rastrear los precedentes de privilegios, ceremonias o usos particulares que se tienen por inmemoriales.

El capellán Hipólito de Samper y Gordejuela, que no en vano escribe a finales del siglo XVII, se interroga sobre la que él llama «Antigüedad confusa», añadiendo «y aunque confusa, como decimos, es Antigüedad, la cual tiene fuerza de ley, y lleva consigo veneración, como aseguran los Juriconsultos». ${ }^{37}$ Este autor, sin embargo, afirma sin titubeos que fue Felipe I El Hermoso el que «introduxo en la Capilla de Castilla el usso de la Cortina, que de muchos años antes se

35. RAH, ms. 9/708, f. 66v. El termino francés sommelier de courtine o sommelier d'oratoire se ve reflejado en Jean Lhermite / C. Ruelens, E. Ouverleaux y J. Petit (ed.), Le Passetemps de Jehan Lhermite publié d'après le manuscrit original, J.-E. Buschmann / A. D. Hoste / Martinus Nyhoff, Amberes / Gante / 'S Gravenhage, 1890-96, II, p. 162. El Abbé Oroux recoge la presencia de sommeliers de la chapelle en fecha tan temprana como 1286. Étienne Oroux, Histoire ecclésiastique de la Cour de France, où l'on trouve tout ce qui concerne l'histoire de la Chapelle, E des principaux officiers ecclésiastiques de nos rois, Imprimerie royale, París, 1776-77, I, p. 369. Véase también Olivier DE LA MARCHE, Mémoires d'Olivier de la Marche maître d'hôtel et capitaine des gardes de Charles le Téméraire, Librairie Renouard / Librairie de la Société de l'histoire de France (Henri Loones, successeur), París, 1883-88, IV, p. 2. Partiendo de los dos sumilleres de ejercicio que prevén las Constituciones se llegan a contabilizar hasta once en 1686. SAAVEDRA ZAPATER, Primer reformismo, p. 30.

36. BHAM, ms. M/25, art. III, ff. 19v-20r.

37. BHAM, ms. M/25, Primera División de la Capilla Real de los Reyes Godos, \$63. Hipólito DE SAMPER Y GORDEJUELA hace retroceder la utilización de la «cortina», en consonancia con el «goticismo» de nuestro Siglo de Oro, a la capitalidad toledana del reino visigodo. Ibid., \$53 y \$57. Las pretensiones al respecto del erudito capellán de la orden de Montesa no son, como en principio pudiera pensarse, infundadas. Conviene no olvidar, por lo pronto, los lazos entre la monarquía visigótica hispana y Bizancio. 
estilaua en Borgoña». ${ }^{38}$ Esta afirmación rotunda entraría en contradicción con lo que recoge Gonzalo Fernández de Oviedo en su Libro de la Cámara Real del Príncipe Don Juan. Si bien es cierto que el manuscrito que nos ha llegado se fecha en 1547-1548, mucho tiempo después del fallecimiento del presunto sucesor de los Reyes Católicos, no resulta verosímil que el autor se engañase al dejar constancia de que los reposteros de capilla «tienen cargo de poner las cortinas e el sitial donde el prinçipe oye misa, e estos lleuan a la camara el sitial e coxines e silla e alhombra adonde se han de dezir las honras a su alteza». ${ }^{39} \mathrm{Si}$, por otro lado, sorprende que Samper no estuviese al tanto del uso de cortinas en la corte del malogrado heredero de Isabel y Fernando, pudiera tratarse de una omisión hasta cierto punto intencionada. En el Libro de la Cámara Real se menciona como parte de los deberes de los reposteros de capilla la custodia de «todos los otros atauios de la capilla». Es decir, desde una óptica reivindicativa de la Real Capilla como organismo independiente cuyos oficios no debían quedar sujetos a la jurisdicción del mayordomo mayor, a Samper no le interesaba en absoluto recordar un precedente palaciego que asignaba la guardia y custodia de los objetos de culto a seglares, más tratándose de una práctica que el capellán de honor denostaba hasta el punto de componer contra ella su Sagrada Defensa de las Reliquias. ${ }^{40}$ La erudición en materia de ceremonias y el origen aragonés de Samper hacen aún menos creíble que desconociese los precedentes, bastante notorios, del uso de oratorios con cortinas entre los monarcas de la Casa de Aragón. ${ }^{41}$ Parece más probable que le interesase enfatizar el linaje borgoñón de la «cortina», obviando el hecho de que la utilización de la misma en 1501 con la llegada de Felipe El Hermoso no debió verse como una innovación, en sentido estricto, ni siquiera en Castilla. Todo apunta a que las cortinas eran ya usadas en la capilla de los Reyes Católicos y ello, lógicamente, como parte de usos aragoneses y castellanos codificados hacía tiempo. ${ }^{42}$ Tanto las Leges Palatinae del rey Jaime III de Mallorca como las Ordinaçions del rey Pedro IV de Aragón (1353) prueban que los oratorios

38. BHAM, ms. M/25, art. III, f. 19v.

39. Gonzalo Fernández de Oviedo y Valdés, Libro de la Camara Real del Prinçipe Don Juan e offiçios de su casa e serviçio ordinario, Sociedad de Bibliófilos Españoles, Madrid, 1870, p. 75.

40. Hipólito de Samper y Gordejuela, Sagrada Defensa de las Reliquias, Calizes, Corporales, Vasos, y Ornamentos de la Real Capilla del Rey nuestro Señor..., s.n., Madrid, 1696.

41. Hipólito de Samper y Gordejuela no solo no ignora las Ordinaçions de Pedro IV sino que acierta a ver en ellas el modelo francés. Respecto a El Ceremonioso apostilla que sus ceremonias palatinas se codificaron «a imitacion de Francia de donde el Rey tomò la mayor parte de los ussos, para formar sus Ordinaciones». BHAM, ms. M/25, Primera División de la Capilla Real de Aragón, y de su Unión con la de Castilla, f. 22v. En realidad, tanto la «cortina» de los reyes de Aragón como el «oratoire» de los duques de Borgoña parecen partir de precedentes regios franceses aunque las vías y modos de transmisión concretos difieran.

42. Desde la perspectiva de la capilla castellana propiamente dicha, la de la reina Isabel I, no contamos con datos inequívocos ya que Lucio Marineo Siculo, L. Marinei Siculi Regii Historiographi Opus de Rebus Hispaniae Memorabilibus, Miguel de Eguía, Alcalá de Henares, 1530, f. 182v, menciona el uso de doseles en la capilla de la Reina Católica sin dejar constancia de si incorporaban o no cortinas. Parece, sin embargo, fuera de toda duda que Juan II de Castilla se servía de «cortinas» en 1453. Costa Gomes, The Royal Chapel, pp. 97 y 106. Véase asimismo Rafael Domínguez Casas, Arte y etiqueta de los Reyes Católicos: artistas, residencias, jardines y bosques, Editorial Alpuerto, Madrid, 1993, p. 213. 
cortinados eran de uso común en la monarquía catalano-aragonesa. ${ }^{43}$ Es más, dejan claro que la costumbre de cambiar el color de la cortina según los tiempos litúrgicos ya estaba en vigor en España desde al menos el siglo XIV. ${ }^{44}$ Pero no es solo el aragonés Hipólito de Samper el que parece olvidar el uso de la cortina entre los monarcas catalano-aragoneses, prefiriendo caracterizar esta práctica como una importación borgoñona. La concordancia de las fuentes del siglo XVII en este punto puede ser calificada de reveladora. Con tres fechas claves sucesivas (1501, 1517 y 1548) la «cortina» fue adoptada y mantenida en Castilla como una práctica ceremonial asociada a la ascendencia borgoñona de los Habsburgo en los que había recaído la corona castellano-leonesa, por más que la práctica misma distase mucho de ser insólita en tierras españolas. Es decir, no es la herencia paterna aragonesa de la reina Juana I la que se invoca para justificar su uso en Castilla. El mencionado Hipólito de Samper, refiriéndose a Carlos V, escribe que en 1517 el futuro emperador «mandó texer su Capilla Real, sobre el fondo de Castilla, con flores de la Casa de Borgoña; haciendo un tan hermoso compuesto, que uniéndose las Grandezas de Ambas, se hizo una nueva, y Nona Marauilla». ${ }^{45}$

A pesar del estilo itinerante de su gobierno, la impronta de Carlos V en «componer» la que será Capilla Real de sus sucesores fue muy significativa. En las Constituciones de 1545 se pormenoriza el modo de disponer en la capilla del Alcázar madrileño el asiento para el legado pontificio justo «enfrente del Oratorio de S.M.». ${ }^{46}$ Como especial marca de distinción, al tratarse de un legatus a latere con poderes plenipotenciarios del Pontífice, se adornaba la pared con una pieza de tapicería del mismo alto que el oratorio regio. Delante de dicha tapicería se colocaba un respaldo de tela carmesí y oro y en el suelo se posaba un estradillo del mismo alto que el del oratorio del rey. Al legado correspondía asimismo una silla de terciopelo carmesí con almohadón, situada detrás de un sitial revestido para poder arrodillarse. Sin embargo, y la aclaración es altamente significativa pues se trata de un símbolo inequívoco de preeminencia y autoridad jurisdiccional, al legado no corresponderá

43. En las Leges Palatinae del rey Jaime III de Mallorca (1337) se mencionan cortinas para el oratorio regio en que se disponen el trono y el reclinatorio dentro de la capilla real a la vez que se especifica que el color de las cortinas habrá de variar en función de la estación litúrgica. Leyes Palatinas - Leges Palatinae, José J. de Olañeta Editor / Conselleria de Cultura, Educació i Esports, Govern Balear, Palma de Mallorca, 1991, III, p. 105. Un pasaje análogo se encuentra en las Ordenacions fetes per lo molt alt senyor en Pere terç rey d'Aragó sobra lo regiment de tots los officials de la sua Cort promulgadas por el rey Pedro IV de Aragón en 1353. B. Palacios Martín (ed.), Llibre de les Ordinacions de la Real Casa de Aragó, Scriptorium Ediciones Limitadas, Valencia, 1994, II, pp. 155-156. El ceremonial de la capilla real de Aragón fue codificado durante el reinado de Juan I (1387-96) siguiendo el modelo de la capilla pontificia de Aviñón. Domínguez CASAS, Arte y etiqueta, p. 222.

44. En las Ordinacions se deja claro que las cortinas serán dispuestas según la variedad del tiempo litúrgico. Libre de les Ordinacions, II, p. 156. Cf. lo expuesto en nota 98.

45. BHAM, ms. M/25, art. III, f. 20r. La realidad, como recuerda Domínguez CASAs, Arte y etiqueta, p. 223, era bastante más compleja, ya que se trataba de una fusión de los usos de Castilla, Aragón, Flandes, Borgoña y de la Santa Sede.

46. Constituciones de la Real Capilla de S.M. reynando el Emperador Carlos Quinto año de 1545, BNM, ms. $14018^{(1)}$ : Advertencia de lo que se executava en la Capilla. 
en ese contexto ningún tipo de dosel o baldaquino. Este tipo de cuidadosa escenificación buscaba reafirmar la autoridad del monarca Habsburgo, cuyo oratorio o «cortina» sí contaba con un «cielo» o pabellón bien visible en el lado del Evangelio, en presencia del representante del Papa. No queda claro hasta qué punto es lícito hablar aquí de usos borgoñones meramente heredados y reproducidos. El oratorio portátil (o fijo) con cortinas de los duques de Borgoña, aun manteniendo una estructura formal y material sustancialmente idéntica, adquiere connotaciones en el arco temporal que se extiende a partir de la llegada a Castilla de Felipe I en 1501 hasta la muerte dos siglos después de su cuarto nieto Carlos II, último de los Austrias, en 1700. Se convierte en cierta manera en una herramienta ceremonial de singular importancia, en una prerrogativa regia -ya no simplemente ducal- celosamente preservada y estratégicamente potenciada. ${ }^{47}$

\section{REGALITATIS OSTENSIO, HUMANITATIS VELATIO}

Los usos y espacios palatinos hispanos difieren no poco de los flamencos, del mismo modo que la estructura de una corte polisinodial como la de los Austrias españoles no puede equipararse a la de los duques de Borgoña que, en cuanto tales, eran, nominalmente al menos, súbditos de los reyes de Francia. Por otro lado, las fuentes documentales no permiten aislar de manera precisa las intenciones de Carlos V y Felipe II al mantener y en cierto modo magnificar, aunque adaptándolo a los usos de Castilla, el legado ceremonial flamencoborgoñón. Pero no cabe duda de que ambos compartían la preocupación por añadir prerrogativas jurisdiccionales y esplendor ceremonial a la que estaba llamada a convertirse en «su» capilla palatina principal. Al hacer de Madrid capital y sede regia estable, Felipe II convierte de hecho a la capilla del antiguo Alcázar de los Trastámaras en la primera de entre sus muchas capillas palaciegas heredadas y ello en virtud de ser la más directamente ligada a su «Real Presencia». La «Real Cortina» como «ceremonia» y «regalía» de la que se valen los reyes austriacos tiende, por encima de cualquier otro aspecto, a realzar la presencia soberana efectiva muy cerca del altar, en una zona adyacente al presbiterio. ${ }^{48}$ No ha de extrañar por lo tanto que su uso no se haga

47. Cronistas y codificadores no tardarán en establecer, en sentido decididamente restrictivo, que se trataba de una prerrogativa imperial o regia. Pedro Salazar de Mendoza / Alonso Carrillo, El origen de las dignidades seglares de Castilla y León, Oficina de Don Benito Cano / Imprenta Real, Madrid, 1657 / 1794, disc. IV, p. 56, nota 4, limitan drásticamente su uso, excluyendo incluso a príncipes electivos y soberanos. Al decir de Salazar de Mendoza, «Poner cortina en los Templos (que es la que llaman Conopeum los Latinos, y Pavillon los Franceses) es regalía peculiar de Grandes Monarcas, que solo dependen de Dios, y de sus espadas».

48. A propósito del origen histórico de la exclusividad sacerdotal del presbiterio, resulta esclarecedora la intervención de Pedro BARCELó BATISTE («De las catacumbas a las catedrales: notas sobre la transformación del espacio sacro desde el inicio de la era cristiana hasta la época teodosiana») en el coloquio mencionado en la nota $(*)$. Los conflictos que enfrentan a Teodosio I con el obispo Ambrosio de Milán y que se resuelven, en el año 391, con la exclusión del emperador del sancta sanctórum, del ábside basilical, permiten a su 
extensivo a los virreyes ${ }^{49}$ y que se reprima la tendencia de algunos miembros de la primera nobleza castellana a servirse miméticamente de ella en sus estados patrimoniales como símbolo de la jurisdicción que les pertenecía dentro de los mismos..$^{50}$ Los Habsburgo harán de la «cortina» una regalía exclusiva de los miembros de su estirpe. Así, los gobernadores de Flandes no usarán de ella en cuanto tales sino, en casos como los de la infanta Isabel Clara Eugenia, ${ }^{51}$ como personas del linaje real. Es más, en cuestiones de puntillosidad ceremonial no fueron a la zaga de sus mayores los tres Austrias menores. La significación de la «cortina» por lo tanto no puede considerarse desde un punto de vista estático. A medida que la Real Capilla iba acumulando privilegios gracias a bulas pontificias impetradas por los monarcas y a medida que el número

vez entender mejor, desde una amplia perspectiva histórica y como me sugirió el mismo Barceló, el que la «cortina» sea, en su intención primaria, un mecanismo ceremonial concebido para acentuar la presencia física y palmaria del rey si no ya en el presbiterio mismo - algo improbable tras lo ocurrido en el siglo IV - al menos en áreas muy inmediatas a este. Nótese al respecto la evidente mesura de Salazar de Mendoza al poner de manifiesto que si bien la «cortina» se alza en el lado del Evangelio, lo hace a una «distancia proporcionada del Presbiterio». Salazar de Mendoza, Origen de las dignidades, disc. Iv, p. 56. A la «cortina», por otro lado, no se accedía por una serie de peldaños como al «haut dais du Roy» utilizado por los monarcas franceses. Así lo recuerda un capellán siciliano de Felipe IV: «[...] ad [Regias Cortinas] per nullos gradus est ascensus, sed contingunt imum pavimentum». Vincenzo Tortoretti, Sacellum Regium hoc est de Capellis et Capellanis Regum liber singularis cum notis perpetuis pro Capella Aulae Hispanae, Francisco Martínez, Madrid, 1630, f. 73v (\$36). Es decir, los capellanes regios tienden a minimizar o cuando menos suavizar lo que la «cortina» hace patente como escenificación del poder soberano en un espacio bajo control eclesiástico, en línea con ese ejemplarizante temor reverencial por el presbiterio que las fuentes atribuían a Felipe II. Porreño, Dichos y hechos, p. 82.

49. Miguel de Cortiada refleja fielmente el rechazo frontal de la Iglesia en época altomoderna a la presencia de «cortinas» o baldaquinos en las iglesias para honorificencias seglares, con la única salvedad de los príncipes soberanos en sus dominios. Miguel DE CortiadA, Decisiones Cancellarii et Sacri Regii Senatus Cathaloniae; sive praxis contentionum et competentiarum Regnorum inclytae Coronae Aragonum super reciproca in Laïcos E Clericos Jurisdictione, Anisson \& Posuel, Lyon, 1699, dec. 286, p. 454 (\$49). Cortiada aceptó el uso de baldaquinos por parte de los virreyes (ibid., dec. 287, p. 459, \$8), mientras que Francisco Ignacio de AÑoA y Busto, Manifiesto canonico, christiano, y politico ... en la disputa, que con ocasion de las Reales Exequias de la Reyna Nuestra Señora Doña Maria Ana de Neoburg, ha ocurrido con el Excelentissimo Señor Conde de Maceda, Virrey... sobre pretender, que su Excelencia havia de usar de dosel en dichas Exequias; y que el Señor Obispo no le avia de poner en ellas, sin embargo de celebrar la Missa de Pontifical ..., José Joaquín Martínez, s.l. [Pamplona], s.d. [1740], p.1, se posicionó en contra, afirmando que era un privilegio exclusivo e intransferible de los reyes. En marzo de 1699 emana de la Congregazione dei Riti un decreto prohibiendo a cualquiera que tuviera la condición de vasallo en Italia la utilización de baldaquinos o doseles en iglesias con la única excepción del virrey de Sicilia. Véase la rica documentación al respecto en AGS, Estado, legs. 3076, 3321, 3323 y 3332 y Secretarías Provinciales (Italia), legs. 317 y 318.

50. Felipe IV llamó la atención del viI duque de Medinaceli por su costumbre de oír misa bajo un dosel con cortinas. José María Dusmet y Alonso, «Visita de la Sociedad Española de Excursiones al Palacio de los Duques de Medinaceli», Boletín de la Sociedad Española de Excursiones, 28/1 (1920), pp. 49-56 (p. 50). Véase el interesante memorial con el que se defiende el aristócrata de la censura del monarca: Antonio Juan Luis DE LA CERDA, duque de Medinaceli, Representación del duque de Medinaceli al Rey Felipe IV sobre haberle mandado el Consejo que quitase la llave dorada á sus criados, no llevase coches descubiertos, y quitase la cortina que habia introducido cuando rezaba en las Iglesias. Prueba ser todo esto unos privilegios de los de su casa (1631), BNM, ms. 18175(30), ff. 117r-119v.

51. La extensión del privilegio a la descendencia y familia legítima del monarca no planteaba problema alguno. Cabría sin embargo analizar los casos de Margarita de Austria o Juan de Austria, Habsburgos de origen ilegítimo. Sabemos que Juan José de Austria, hermano bastardo de Carlos II recién ascendido a primer ministro, fue expresamente excluido de los honores de la cortina por Real Decreto de 1 de abril de 1677. Véase Antonio Álvarez-Ossorio Alvariño, «Ceremonial de la Majestad y protesta aristocrática. La Capilla Real en la corte de Carlos II», en La Capilla Real, pp. 345-410 (pp. 375-378). 
y cualificación de las personas que en ella servían aumentaban, el papel más palmario de la «cortina»-cual era el de acotar un espacio exclusivo para el monarca en las inmediaciones del altar- inevitablemente adquiría protagonismo. En términos espaciales, la «cortina» servía de referente de todo el sistema de «asientos» de la Real Capilla [Fig. 4] que, ${ }^{52}$ con las variaciones del caso, era exportable a cualquier iglesia de sus reinos en la que la majestad católica asistiese de manera pública [Fig. 5], sin exceptuar la Sede Primada de Toledo [Fig. 6]..$^{53}$ En ningún otro ámbito palaciego como la capilla se hacía tan evidente la preeminencia absoluta e intransferible del monarca, su unicidad dentro de una compleja jerarquía palatina en la que participaban e interaccionaban eclesiásticos y seglares.

En abril de 1562 se rumorea que Felipe II va a ser proclamado rey de las Indias y del Nuevo Mundo; en enero de 1563 y de 1564 se apunta que será declarado emperador de las Indias, supuesto que aún circulará en fecha tan avanzada como $1583 .{ }^{54} \mathrm{Si}$ las veleidades imperiales del Rey Prudente parecen ganar ímpetu en 1562, el año anterior registró dos hechos de capital importancia en la acuñación de la realeza filipina: la elección del lugar de El Escorial para la fundación del panteón dinástico y el decreto erigiendo en capital a la villa de Madrid. Todo ello da la medida de la centralización simbólica del poder bajo Felipe II y permite entender mejor la inusitada importancia que adquiere la Real Capilla del Alcázar en ese marco político. Es un contexto en el que las tensiones entre el Papado y el monarca español se dejan sentir con fuerza. Huelga decir que las reivindicaciones regalistas de la casa de Austria no son ajenas a la consciente exaltación de la capilla palatina como foro privilegiado de la ancestral pietas Austriaca. En efecto, en 1565, con motivo de la celebración de los concilios provinciales, reconocidos como un punto de inflexión en la Contrarreforma española, se recrudecen las tensiones entre la Santa Sede y Madrid. El secretario de Estado de la Curia, cardenal Altemps, se lamentaba de las instrucciones promulgadas por Felipe II al respecto y se quejaba de «esa voz escandalosa que quizá haya salido de algún personaje del Consejo, que en España no hay Papa». ${ }^{55}$ La referencia le llegó a Altemps del Cardenal Giambattista Castagna, que había acompañado al legado Ugo Boncompagni, futuro Gregorio XIII, a España ese mismo año y que sucedió a Alessandro

52. Debido en sus líneas maestras a la reina Isabel I de Castilla y por lo tanto no borgoñón, se trataba de un sistema que dictaba las correlaciones espaciales e itinerarios ceremoniales, publicitando en un lugar de culto los escalafones cortesanos. BHAM, ms. M/34, parte II, ff. 13v y 30v-31r. SALAzAR DE MENDOZA, Origen de las dignidades, disc. IV, pp. 53-54.

53. Ángel Fernández Collado / Alfredo Rodríguez González / Isidoro Castañeda Tordera, Los diseños de la Catedral de Toledo. Catálogo de diseños arquitectónicos, artísticos, topográficos y textiles, Cabildo Primado, Catedral de Toledo / Instituto Teológico San Ildefonso, Toledo, 2009, pp. 52 y 289-290 (núm. 199).

54. Fernand Braudel, The Mediterranean and the Mediterranean World in the Age of Philip II, University of California Press, Los Ángeles / Londres, 1995, II, p. 675.

55. Luciano Serrano, osb, Correspondencia diplomática entre España y la Santa Sede durante el pontificado de S. Pío V, Junta para la Ampliación de Estudios e Investigaciones Científicas: Escuela Española en Roma, Madrid, 1914, I, apéndice I, pp. 443-446. 
Crivelli en la nunciatura madrileña. Se atribuía el dicho a Juan Rodríguez de Figueroa, presidente del Consejo de Castilla. Y si las tensiones en materia de jurisdicción eclesiástica serán una constante tanto para los Austrias mayores como menores, Felipe II se mostró especialmente firme en la defensa de las que entendía como sus prerrogativas regias.

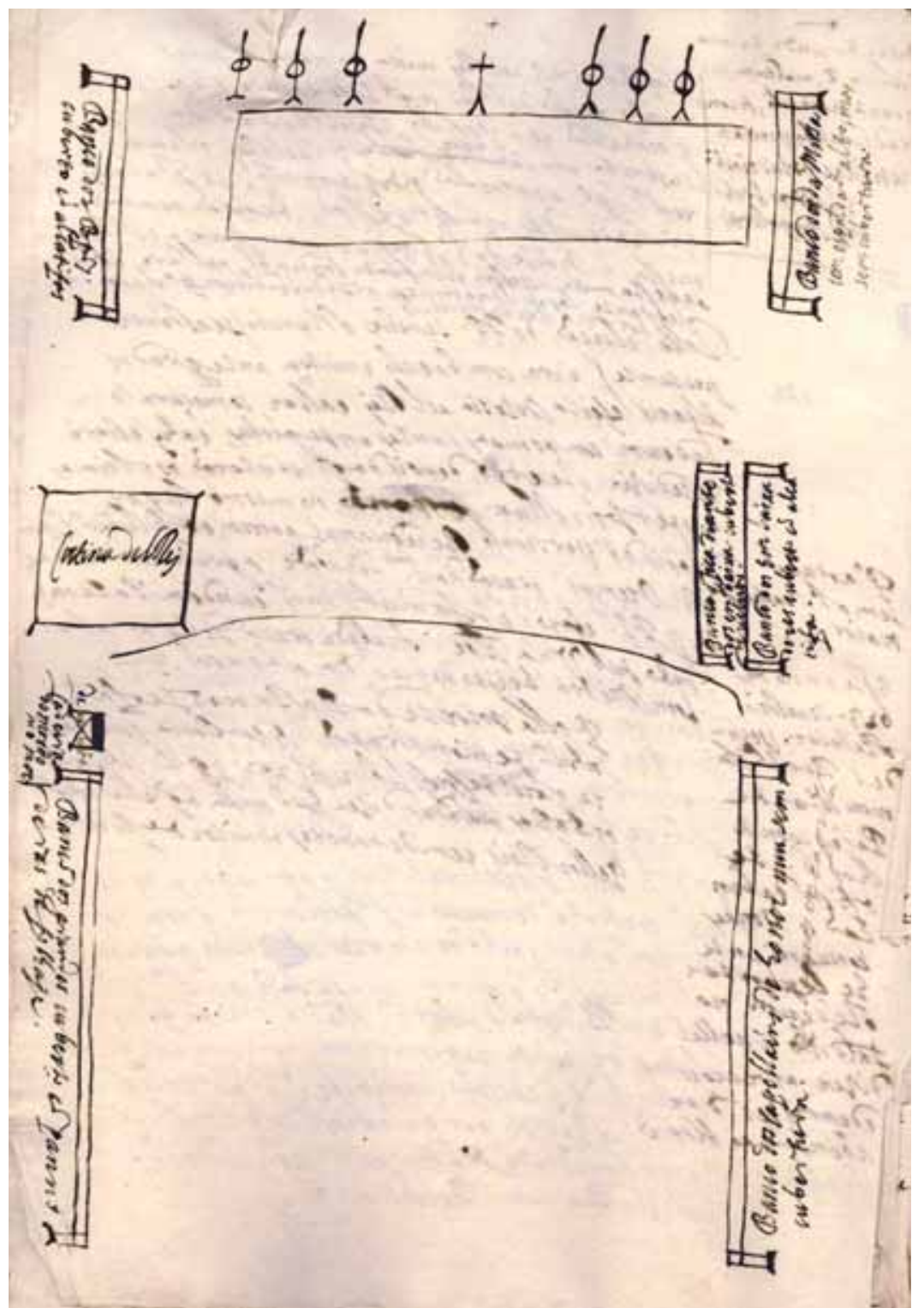

Fig. 4. Manoel Ribeiro: Rasguño de la planta de asientos de la Real Capilla del Alcázar de Madrid mostrando en el centro, a la izquierda, la «Cortina del Rei» (c. 1620-22) en Memoria dos costumes q' nesta Real Cap ${ }^{a}$ de Madrid sessaó estando sua Mag. ${ }^{d e}$ presente. Tinta negra sobre papel verjurado, aprox. 213 x 312 mm. Archivo General de Palacio, Real Capilla, caja 93, exp. 3 ○ Patrimonio Nacional, Madrid 


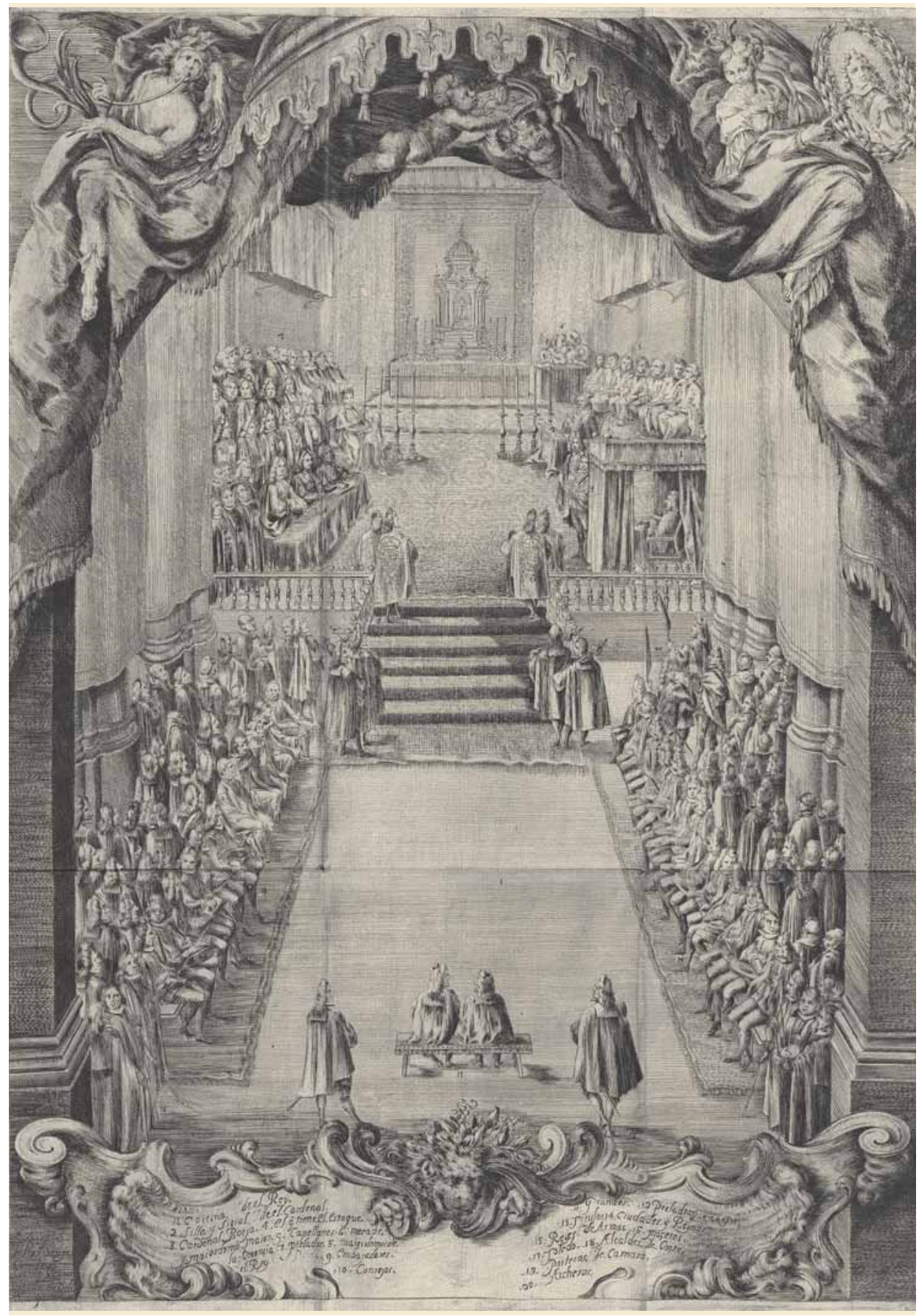

Fig. 5. Pedro DE Araujo: Jura de Felipe V en la Iglesia de San Jerónimo El Real (Madrid) en Juramento y Pleyto Omenage que los Reynos de Castilla y León, por medio de sus Capitulares, y los Prelados, Grandes, y Titulos, y otras personas, hizieron el dia 8 de Mayo de 1701 de A. de Ubilla y Medina (1702). Grabado, 551 x 390 mm (huella de impresión). Biblioteca Nacional, Madrid, sign. ER/1637 


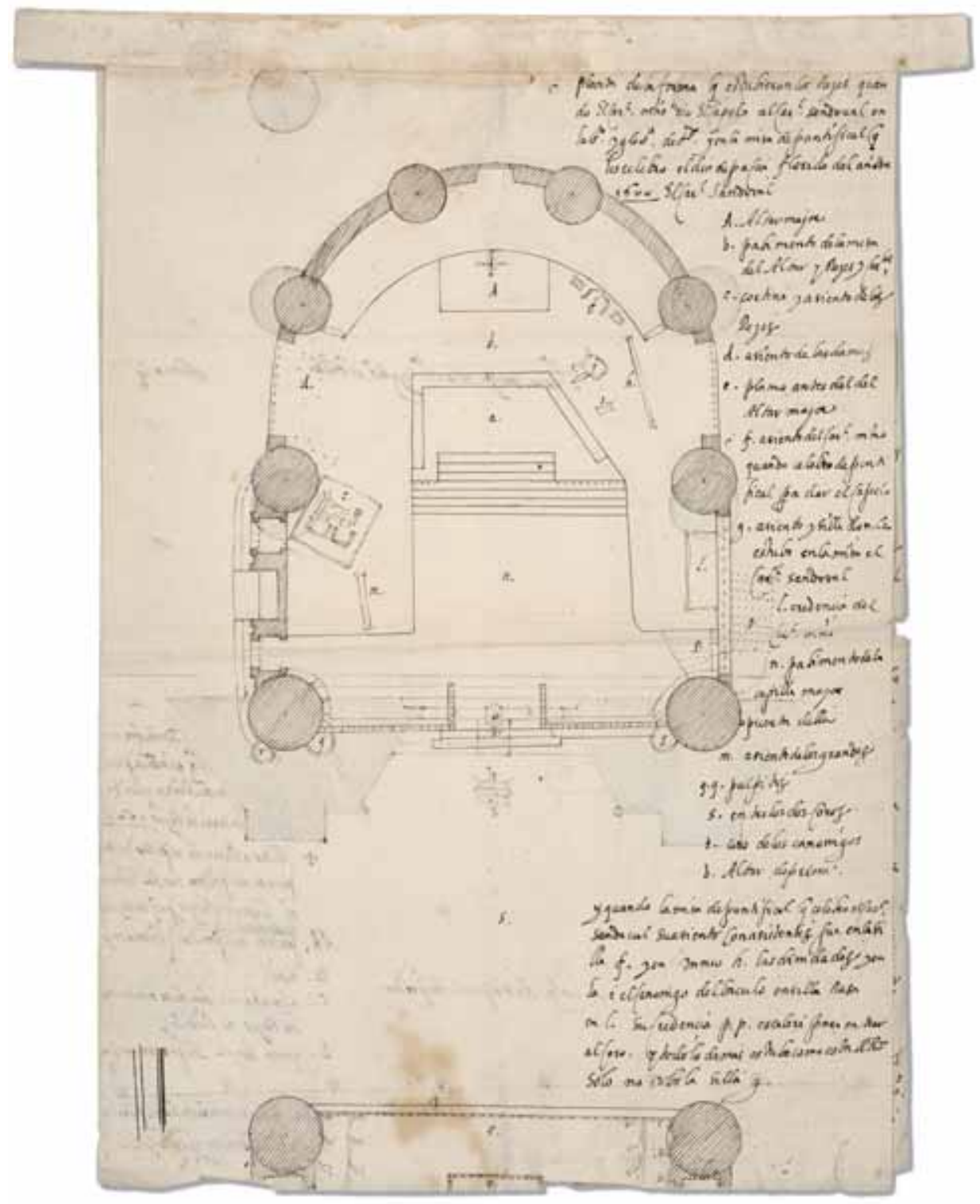

Fig. 6. Anónimo: «planta de la forma q[ue] estubieron los Reyes quando El Car. ${ }^{1}$ niño dio El Capelo al Car. ${ }^{1}$ Sandoual en la s. ${ }^{\text {ta }}$ Igles. ${ }^{a}$ de t. ${ }^{\text {do }}$ y en la misa de pontifical q[ue] les celebro el dia de pascua florida del año de 1600 El Car. Sandoual» (c. 1604). Tinta negra sobre papel, 377 x 246 mm. Archivo Capitular, Catedral de Toledo, Colección de diseños, núm. 199

A este monarca se le reconoce con justicia un papel fundamental en la articulación del concepto altomoderno de realeza, aspecto en el que posiblemente solo podría aventajarle su biznieto Luis XIV. De ese concepto, de esa definición de la majestad, era indisociable la ejemplaridad del propio monarca en el culto religioso de acuerdo a unos patrones que, en el caso 
del monarca español, llaman la atención por ser extrañamente (¿también deliberadamente?) vetustos. Con certero juicio, al estudiar la cabecera de la basílica escurialense, Fernando Chueca Goitia se decanta por definirla como un «abrazo místico» de eucaristía y monarquía, subrayando así los referentes bajomedievales desde los que Felipe II parece concebir su oficio regio en proximidad al altar o, como escribe el arquitecto e historiador madrileño, en estremecedora «religación entre el altar, el tabernáculo y la cámara regia». ${ }^{56}$ Estas sagaces y reveladoras palabras de Chueca, pensadas para el monasteriopalacio de El Escorial, son igualmente aptas para describir la mecánica ceremonial que se desplegaba en el interior del Alcázar los «días de cortina» en los que el rey asistía públicamente a su Real Capilla. Como verdadero motor o reloj de todo el mecanismo ritual -este bello símil se lo debemos también a las reflexiones escurialenses de $\mathrm{Chueca}^{57}$ - el soberano partía desde lo reservado de su alcoba a través de una secuencia de espacios en cuidada gradación, de más privado a más público, de menos a más accesible. ${ }^{58}$ Las más altas jerarquías eran por lo tanto aquellas que se sumaban antes al «acompañamiento» que desde la cámara regia se dirigía hacia la capilla. Adoptando este punto de vista procesional, diríamos que se trata de una progresión ad publicum que se dirige desde lo profundo de la alcoba regia con su lecho «de respeto» hacia un espacio de comparecencia ante los ojos de los cortesanos como lo es, a pesar de su escasa superficie útil ${ }^{59}$ la capilla palatina. Es sin embargo la estructura misma de la «cortina», como oratorio portátil destinado a la persona regia, la que de algún modo problematiza esta lectura unidireccional. La «cortina», al estar dotada de elementos tan dinámicos como las cortinas correderas, puede servir precisamente para sugerir diferentes grados de permeabilidad y de visibilidad entre la persona del rey y el altar por un lado y la del rey y el resto de los asistentes por otro. Dicho de otro modo, la «cortina» conlleva, inevitablemente, dos lecturas superpuestas: una, de cortinas descorridas, claramente ad publicum, que reafirma y publicita la proximidad del rey al altar, en lo que no puede ser sino una afirmación de las regalías de la corona y de la misión divinamente asignada de los reyes, y otra ad privatum, de cortinas

56. Fernando Chueca Goitia, Casas Reales en monasterios y conventos españoles, Xarait Ediciones, Madrid, 1982, pp. 144-145 (publ. orig. Real Academia de la Historia, Madrid, 1966).

57. El monasterio, especie de «reloj litúrgico» o de «cadrán gigantesco», se asemeja a un «inmenso reloj cuya delicada maquinaria servía para enlazar, de una manera trascendente, o si se quiere teológica, el mundo y el trasmundo». Fernando Chueca Goitia, «El Escorial», ABC de Sevilla, 30 de enero de 1980, p. 3. Ídem, «El Escorial a través del espíritu de su fundador», Revista de Occidente, I/1 (abril de 1963), pp. $80-99$ (pp. 85 y 90-91).

58. El complejo mecanismo de gradación de espacios en el interior del Alcázar llama, tempranamente, la atención de estudiosos como PFAndL, Felipe II, pp. 143-145, y continúa despertando interés hasta llegar a interpretaciones como la que, desde la antropología cultural y con un gráfico esclarecedor, aporta Carmelo Lisón Tolosana, La imagen del rey. Monarquía, realeza y poder ritual en la Casa de los Austrias, Espasa Calpe, Madrid, 1992, p. 142. Dentro de un contexto amplio, véase el afinado análisis comparativo de Marie-France Auzépy / Joël Cornette, «Lieux de pouvoir, pouvoir des lieux» en Palais et Pouvoir. De Constantinople à Versailles, Presses Universitaires de Vincennes, Saint-Denis, 2003, pp. 5-31 (pp. 10-12). $\left.180 \mathrm{~m}^{2}\right)$.

5. Descontando el cancel, venía a medir, tras la reforma de 1698-1702, 21,9 x 8,3 m (o poco más de 
corridas, que confiere al rey la privacidad de un oratorio propio en medio de una ceremonia pública.

Todo ello viene a ratificar el carácter eminentemente público del apretado espacio de la capilla, con la única y significativa excepción del oratorio fijo (llamado «cancel» o tribuna) a sus pies, reservado al culto y misa privados del monarca y equipado con portezuelas y ventanas con vidrios [Fig. 7]. ${ }^{60}$ Por el contrario, la presencia del rey en el oratorio portátil -la célebre «cortina» de la que venimos hablando- connotaba la celebración como «pública», prueba evidente de que no perseguía, como pretendía la princesa de los Ursinos, el objetivo de ocultar la presencia y participación del rey en el acto litúrgico sino muy al contrario el de realzarla. Con mayor propiedad diríamos que se trataba de un dispositivo ceremonial intencionadamente ambivalente, capaz de funcionar casi simultáneamente como oratorio regio con dosel y cortinas recogidas y como oratorio privado a modo de «cama colgada» ${ }^{61}$ que reservaba para el monarca un espacio de privacidad en aquellos momentos de la celebración en los que procedía hacerlo. En efecto, entre las virtualidades de la «cortina» estaba precisamente la de preservar en las misas y vísperas solemnes, obviamente públicas, ese contacto visual íntimo entre el monarca y el altar al que hacía referencia Chueca a propósito del ábside escurialense: la cortina «frontera» permanecía parcialmente descorrida para que el rey pudiese contemplar ininterrumpidamente la mesa de altar incluso en aquellos tiempos litúrgicos en los que el sumiller corría las restantes cortinas del oratorio. ${ }^{62}$ Sobre ello insistiremos más adelante, pero no sería arriesgado adelantar la hipótesis de que Felipe II no solo mantuvo el uso de la «cortina» como parte de un legado dinástico especialmente valioso por venirle de su imperial padre ${ }^{63}$ sino que supo captar su versatilidad y servirse de ella con miras a acentuar y

60. El «cancel» consistía en un modesto espacio tripartito acotado mediante paneles de madera al que se accedía por los pies de la Real Capilla, comunicándose con el resto de la misma mediante ventanas acristaladas (fig. 7, bajo las letras R S S). El espacio libre sobre el «cancel» se aprovechó en época de Felipe II para instalar dos niveles superpuestos de balcones o palcos destinados a las damas y a los músicos. Véronique GÉRARD, «Los sitios de devoción en el Alcázar de Madrid: capilla y oratorios», Archivo Español de Arte, 56/223 (1983), pp. 275-284 (p. 277). La coexistencia de «cortina» y «cancel» venía asociada al ceremonial franco-borgoñón. El segundo ofrecía para la familia real -y especialmente para la reina- un palco privado desde el que asistir a las ceremonias públicas en la Real Capilla a la vez que, si así se deseaba, podía funcionar aisladamente como oratorio para ceremonias y devociones de carácter privado. TorTORETTI, Sacellum Regium, f. 73r (\$35).

61. Los capellanes de época borbónica recuerdan que el que «en este tiempo se llama propiamente Sitial del Rey» en la Real Capilla, «en lo antiguo constaba de varias partes en forma de cortinas, à la manera que las tiene una cama colgada». BHAM, ms. M/34, Parte II, f. 31rv.

62. Durante el sermón, la cortina «frontera» del altar o, dicho de otro modo, la cortina que daba al altar, permanecía abierta. AGP, Real Capilla, 94/1. Felipe IV invitó a Ana María Luisa de Orleáns, la célebre «Grande Mademoiselle», a acompañarle en la real «cortina» mientras ambos asistían a misa en Fuenterrabía. Según la princesa francesa «le rideau qui regardait l'autel étoit ouvert [...] le roi dit que l'on tirât le rideau du côté où j'étois, afin que l'on le vît mieux, même il fit signe à des aumôniers de se ranger, de peur qu'ils n'empechassent de voir» (SABATIER, Le roi caché, p. 122).

63. BHAM, ms. M/25, art. III, f. 21rv. Véanse los libros de horas repr. en Kaiser Karl V. (1500-1558) Macht und Ohnmacht Europas, Kunst- und Ausstellungshalle der Bundesrepublik Deutschland / Kunsthistorisches Museum, Bonn / Viena, 2000, pp. 345-347 (cat. núm. 404 por Ulrike BECKER y cat. núm. 405 por William VOELKLE) 
acrecentar, en un lenguaje simbólico-ritual, las singulares regalías a las que se sentía acreedor como rey católico que ostentaba a su vez la primogenitura de la casa de Austria.

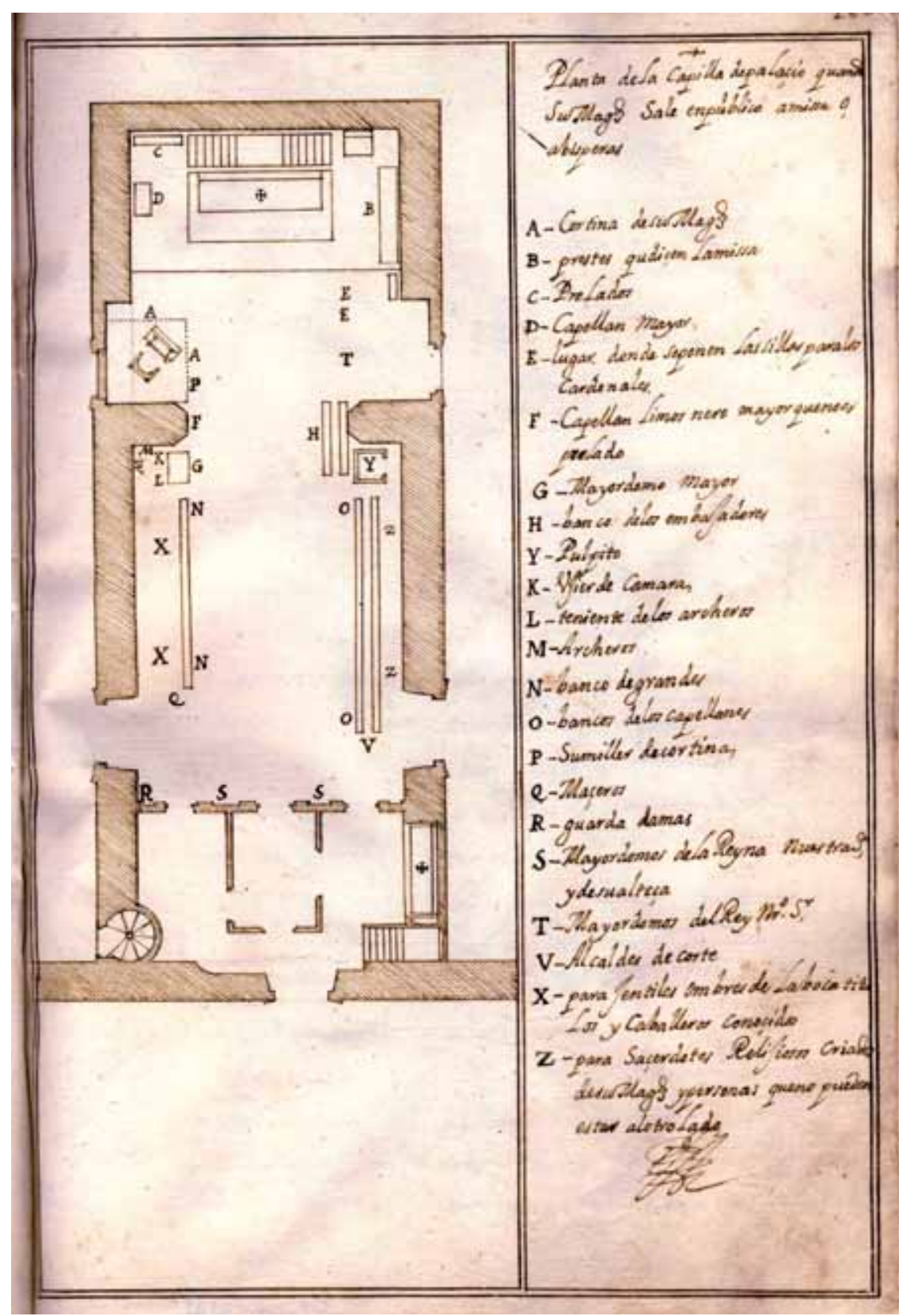

Fig. 7. Juan Gómez de MorA: «Planta de la Capilla de palaçio quando Su Magd Sale en publico a missa o, a bisperas» (c. 1650). Tinta parda sobre papel verjurado, 195 x $286 \mathrm{~mm}$ (recuadro). Archivo General de Palacio, Sección Histórica, caja $51^{(1)}$, f. 186r ๔ Patrimonio Nacional, Madrid 
Los capellanes que escriben a lo largo del siglo Xvil sobre la historia de la Real Capilla hispana la definen con exactitud, demostrando su rigor y la disponibilidad de los ricos fondos manuscritos de la capellanía mayor, que nos han llegado solo de modo fragmentario, la más de las veces a través de copias posteriores o compilaciones parciales ${ }^{64}$ Capellanes como el portugués Manoel Ribeiro, el siciliano Vincenzo Tortoretti, el besanzonés Jules Chifflet, el sardo Mateo Frasso o el aragonés Hipólito de Samper dan la medida de la internacionalidad de la Real Capilla al servicio de la dinastía austriaca. Destaca igualmente la consciencia compartida de pertenecer a una institución de primer orden dentro de la Monarquía Hispánica, a un banco de capellanes que -según Frasso- merece ser reconocido «en todo el mas decoroso, y perfecto, que se conoce en muchos, y dilatados Reynos». ${ }^{65}$ Son asimismo conscientes, y los documentos de los que disponen y que citan diligentemente lo avalan, de la configuración progresiva de los ritos y ceremonias a lo largo de los sucesivos reinados, con puntos fijos de especial relevancia: la compilación filipina protagonizada por el capellán mayor García de Loaysa, la subsiguiente de Álvaro de Carvajal bajo Felipe III y las mejoras de las Constituciones de la Real Capilla que se ultimaron en los inicios de la privanza de Olivares, en 1623, durante la capellanía mayor de Diego de Guzmán, futuro arzobispo de Sevilla. La compilación que quedará como referente más difundido de las «etiquetas» palatinas se ultima bajo la mayordomía mayor del duque de Medina de las Torres, en el periodo post-olivarense, formadas por Real Decreto de 22 de mayo de 1647 y publicadas en $1651 .{ }^{66}$ Son estas de extraordinaria utilidad para conocer los rituales de la Real Capilla entre otros motivos por ir acompañadas de una serie de dibujos ilustrativos, de «plantas», de mano de Juan Gómez de Mora [Fig. 7 y 8]. Pero importa recalcar que, por lo que toca a la capilla, no se puede hablar realmente de innovaciones significativas, tratándose sencillamente de una codificación detallada de los usos palatinos, por lo demás tampoco nuevos, ilustrada para servir de guía fiel y autorizada a los oficios y cargos seglares de la Real Casa y no al clero de la Real Capilla.

Como venimos insistiendo, todos los precedentes y toda la exégesis en torno a esta práctica son concordes: el uso de la «cortina», del cubículo cortinado, desempeñaba una compleja función que no puede, sin distorsión mayor, calificarse de ocultación. Los «días de cortina» en la Real Capilla eran siempre días en los que el rey, por tratarse de una solemnidad señalada, acudía

64. Un grupo de musicólogos llevó a cabo un rastreo sistemático de fuentes manuscritas relativas a la Real Capilla, la mayoría de las cuales se conservan en bibliotecas y archivos madrileños. Véase Luis ROBLEDO Estaire / Tess Knighton / Cristina Bordas Ibáñez / Juan José Carreras López, Aspectos de la cultura musical en la Corte de Felipe II, Editorial Alpuerto / Fundación Caja Madrid, Madrid, 2000, pp. 409-420.

65. BHAM, ms. M/34, cap. 6, p. 87.

66. AGP, Sección Histórica, caja $51^{(1)}$ : Copia de las etiquetas grâles que habian de observar los Criados de S.M. en el uso y ejercicio de sus oficios, y en las diversas funciones á que asisten las Personas R.s, con algunos ejemplares de Gacetas de Madrid, que contienen disposicion. ${ }^{s}$ relativas al mismo objeto, segun $R .{ }^{l}$ Decreto de 22 de Mayo de 1647. 


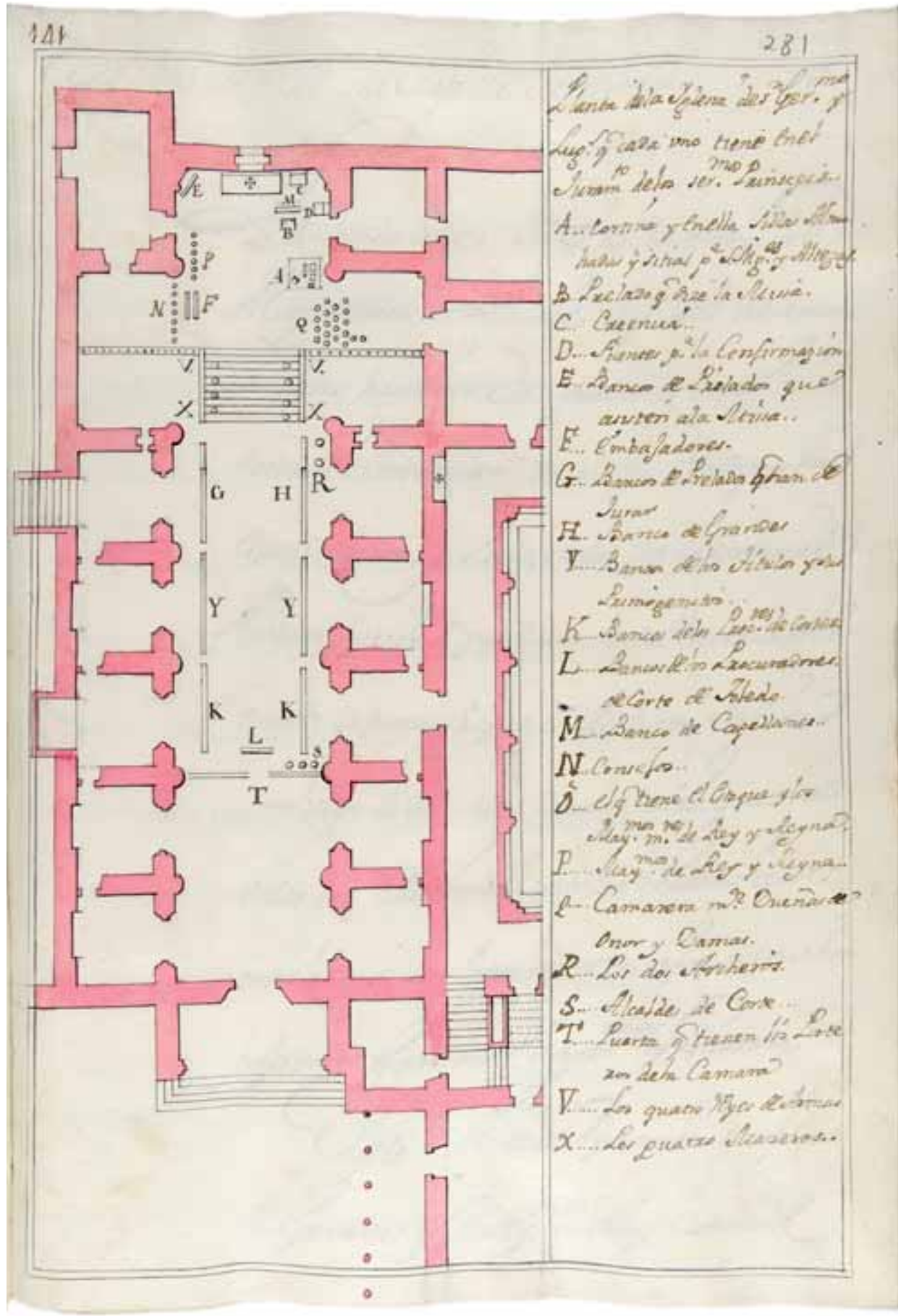

Fig. 8. Anónimo según J. Gómez de Mora: «Planta de la Yglesia de $S^{\mathrm{n}}$ Ger. ${ }^{\mathrm{mo}}$ y Lug. ${ }^{\mathrm{s}} \mathrm{q}$ cada vno tiene en el Juram. ${ }^{\text {to }}$ de los ser. ${ }^{\text {mos }}$ Principes» de las Etiquetas de las Reales Casa y Cámara de S.M. (1731). Tinta parda y negra y acuarela rosa sobre papel verjurado, 188 x $277 \mathrm{~mm}$ (recuadro). Biblioteca Nacional, Madrid, ms. 9147, f. 281r 
«en Público». ${ }^{67}$ Ante la inminencia de la llegada del soberano correspondía al enguantado sumiller descorrer las cortinas de la «cortina ${ }^{68}$ y quitar el terliz que cubría reverencialmente el reclinatorio y la silla regios. Una vez situado el rey dentro del cubículo, el sumiller corría las cortinas media y trasera dejando parcialmente descorrida la frontera, la que daba al altar. Como preludio de rituales en los que había de intervenir el monarca, se volvían a descorrer las cortinas, quedando este -la expresión es importante- «patente» ante su corte en la que podríamos definir como una verdadera ostensio regis. ${ }^{69}$ Los momentos en los que entraba o salía, aquellos en los que debía ausentarse para hacer ofrecimientos al altar, o aquellos en los que el eclesiástico de mayor dignidad se acercaba para recitarle el confíteor, para acercarle a besar el portapaz o los evangelios o el lignum crucis, para incensarle o para llevarle la comunión, constituían todos ellos actos «públicos» en los que el rey quedaba plenamente visible a la asistencia. ${ }^{70}$ Eran además ceremonias que se llevaban a cabo in cornu evangelii [Fig. 4 y 7 ], ${ }^{71}$ materializándose como prerrogativas

67. Dias en que su Magestad (que Dios guarde) sale à la Capilla Real publica, ò privadamente para assistir en la Cortina, ò en la Tribuna, y la hora en que empieçan en ella los Divinos Oficios, s.n., s.l. [Madrid], 1681. Véase RAH, ms. 9/708, ff. 135v-145v.

68. El sumiller de cortina hacía primero una reverencia al altar y luego otra al rey antes de besar la mano con la que procedía a abrir la «cortina». Lo mismo se verificaba al cerrarla. AGP, Real Capilla, 94/1.

69. En palabras de Matteo Frasso, por ejemplo, el sumiller de cortina no hará ejercicio de sus funciones en la festividad de Santiago ya que en ella «S.M. está patente, y sin Tusón». RAH, ms. 9/708, f. 141v. La «cortina» de hecho funciona de manera distinta en oficios propiamente litúrgicos (como vísperas y misas solemnes) y en ceremonias regias que tienen lugar en iglesias (como reuniones de capítulos o juras solemnes, fig. 5 y 8). En el segundo de los casos, su ambivalencia se reduce notablemente y pasa a ser, en lo esencial, un trono con dosel y cortinas recogidas a los lados. Véase al respecto la interesante descripción de la jura del príncipe Baltasar Carlos por Vincenzo Tortoretti, Inauguratio Serenissimi Balthasaris-Caroli Asturiae et Hispaniarum Princeps, Francisco Martínez, Madrid, 1632, f. 6r (subrayados añadidos): «Sequebantur Regiæ cortinæ altiores \& ampliores quàm in Sacello Aulæ eriguntur illas de more deduxit \& reduxit Præfectus eisdem, dum tamen res divina facta est. Quâ peractâ, eius opera cessavit: nam sublatum fuit Lectisternium à Custode Supellectilis Regiæ, \& à Metatore, \& deductâ cortinâ anterior ex utroque latere: remansit posterius, \& supernum velum, quæ usum amplissimi Vranisci præbuêre. Ita cunctis apertum patuit Regium Solium, in quo personæ Regiæ hoc modo consedêre».

70. Al describir los llamados actos públicos en la cortina, el capellán Manoel Ribeiro especificó que la «cortina» debe quedar en esos momentos «un poco mas abierta de lo acostumbrado» (AGP, Real Capilla, 94/1), lo que viene a rubricar que la misma no permanecía nunca completamente cerrada mientras estuviese en ella el rey. El ósculo de los Evangelios, la incensación del rey y el beso del portapaz eran las tres ceremonias principales que se llevaban a cabo a cortina abierta, con el rey patente. Manoel Ribeiro, Caeremoniale orationis Sanctissimi Sacramenti, quae singulis mensibus in Regia habetur, Typographia Regia, Madrid, 1668, f. 47v: «Si autem Rex adsit semper, primo illi liber Euangelistorum, thus, \& pax sunt ministranda [...]». Véase Jean Sigoney, Relación de la forma de servir que se tenía en la Casa del Emperador Don Carlos [1545], BNM, ms. 907, f. 50r. Sabemos asimismo que cuando el rey asistía a misa privadamente, ya fuera en el «cancel» de la Real Capilla de Madrid o en sus aposentos de El Escorial, no se le daban a besar los Evangelios «ni se le hace singularid. d alguna». Matteo FrAsso, Capilla Real de Castilla [1696], BHAM, ms. M-34, cap. 6, p. 107.

71. Como se dijo en nota 48, la «cortina» se situaba en el lado del Evangelio («iuxta cornu Evangelij») y cerca del altar («prope aram») pero fuera del presbiterio. Junto a la «cortina» permanecía de pie el sommelier de courtine para abrir o cerrar las cortinas («Proximus sequitur Praefectus Regijs cortinis deducendis, \& reducendis, qui semper adstat»). TortoretTi, Sacellum Regium, 1630, f. 73v (\$36). Un oportuno y documentado análisis del ceremonial de capilla en la turbulenta corte de Carlos II dedica espacio tanto a la «cortina» de los Austrias como a sus antecedentes históricos. Véase Álvarez-Ossorio Alvariño, Ceremonial de la Majestad, pp. 354-358. Prueba de que la posición de la «cortina» en el lado del Evangelio y pasado el arco toral era absolutamente privilegiada, en el ms. La Fleur des histoires de Jean Mansel el 
regias. Por otro lado, cuando la cortina se corría, el rey mantenía un grado de proximidad e intimidad respecto al altar que, significativamente, no compartía con su corte. Digámoslo una vez más, coexisten en la «cortina» un rey patente e institucional y un rey humano y mortal que no se muestra, recogido en sus plegarias y devociones. Esa articulación dinámica, ceremonial, de la dualidad regia, ${ }^{72}$ tiene raíces profundas en la cultura europea, como pusiera de manifiesto Ernst H. Kantorowicz en su magistral The King's Two Bodies. ${ }^{73}$ Aunque quede mucho camino por recorrer en el estudio de la concreción propiamente ritual y artística de esa concepción dual del rey como receptáculo mortal de una institución imperecedera, la senda correcta fue trazada hace tiempo gracias al seminal estudio de Ralph Giesey sobre los rituales fúnebres de la monarquía francesa ${ }^{74}$ y a las agudas observaciones de Erwin Panofsky relativas a la aparición en la escultura funeraria francesa de double gisants en los que se superponían cadáveres de un patetismo estremecedor (representación en transi) y cuerpos gloriosos (representación $a u v i f$ ). ${ }^{75}$ No se olvide que el uso hispano-borgoñón de la «cortina» en el que aquí hemos fijado nuestra atención es, no por casualidad, de inequívoca filiación medieval francesa. ${ }^{76}$

oratorio portátil se eleva fuera del arco y en el lado de la Epístola. Véase Olga Pérez Monzón, «Ceremonias regias en la Castilla Medieval. A propósito del llamado Libro de la Coronación de los Reyes de Castilla y Aragón», Archivo Español de Arte, 83/332 (2010), pp. 317-334 (pp. 320-321).

72. Las más pormenorizadas descripciones de las ceremonias que se llevaban a cabo en la capilla palatina de los Austrias españoles se las debemos a Matteo Frasso, un concienzudo capellán de origen sardo al servicio de Felipe IV y de Carlos II. Receptor de la Real Capilla desde 1661, este agudo y meticuloso observador nos ha dejado una referencia nítida y muy significativa a la bicorporeidad regia: «representando los Principes dos

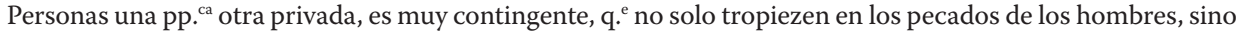
tambien en los de los Reyes, [...]». Frasso, Capilla Real, BHAM, ms. M-34, cap. 5, p. 68.

73. Ernst H. Kantorowicz, The King's Two Bodies: A Study in Mediaeval Political Theology, Princeton University Press, Princeton (Nueva Jersey), 1997 (publ. orig. Princeton UP, Princeton, 1957).

74. Ralph E. GIESEY, Cérémoniel et puissance souveraine: France, $X V^{e}-X V I I^{e}$ siècles, Éditeur Armand Colin, París, 1987.

75. Con meridiana claridad establece Panofsky: «Above the transi, expressing the corruptibility of the individual body, there could be seen, as usual, the representacion au vif symbolic of what may be called the terrestrial permanence of preterindividual dignity». Erwin PANOFSKY / H. W. Janson (ed.), Tomb Sculpture: Its Changing Aspects from Ancient Egypt to Bernini, Thames and Hudson, Londres, 1964, pp. 64-66 y 78-81 y fig. 261-266, 324, 331, 342-351, 354, 356-358, 360-362 y 364-366 (la cita ut supra en p. 65). Jacques Le GoFF, «Saint Louis et les corps royaux», Le temps de la réflexion, 3 (1982), pp. 255-284 (pp. 273-275).

76. Nada lo ilustra mejor que la celebrada serie de extraordinarios códices miniados encargados por Juan I, duque de Berry, hijo de Juan II de Francia, a varios miniaturistas entre los que se contaban los neerlandeses hermanos Limburg. Con fechas de ejecución entre 1372 y 1416, la utilización de la courtine $\mathrm{u}$ oratoire y la presencia de su correspondiente sommelier quedan ampliamente documentadas en estos pergaminos. Véanse: M. Thomas (ed.), Les Grandes Heures de Jean Duc de Berry (Bibliothèque nationale Paris ms. lat. 919), Thames \& Hudson, Londres, 1971, ff. 16r, 34v, 97r y 98r; Les Petites Heures du duc de Berry ms. lat. 18014 Bibliothèque nationale, Paris, Éditions Facsimilé, Lucerna, 1988, ff. 97v, 106rv, 115v, 119r, 121v, 122v, 139r, 144v, 145v, 167v, 169v, 170v, 171r, 172r, 173v, 174v y 176rv; M. Meiss y E. H. Beatson (ed.), Les Belles Heures de Jean Duc de Berry, Thames \& Hudson / The Metropolitan Museum of Art, Londres / Nueva York, f. 91rv; R. Cazelles y J. Rathofer (ed.), Les Très Riches Heures du duc de Berry. Ms. 65 Musée Condé de Chantilly, Faksimile-Verlag, Lucerna, 1984, f. 158r. Para el f. 81v del Livre d'heures (p.q. 1436) de otro príncipe de estirpe capetina, el angevino Renato I, rey de Nápoles, véase Christian DE MérINDOL, $L e$ roi René et la seconde maison d'Anjou: emblématique, art, histoire, Le Léopard d'Or, París, 1987, pl. xxxII, núm. 130. Excepcionalmente detallada es la conocida miniatura en la que aparece Felipe El Bueno, duque de Borgoña, en misa (Bibliothèque royale, Brussels, ms. 9092, f. 9) reproducida en este artículo: véase fig. 2. 
Dadas estas premisas, resulta especialmente pertinente preguntarse por las potenciales connotaciones que adquieren en época altomoderna ritos y tradiciones ligados al rey bicorpóreo bajomedieval. La hipótesis que aquí planteamos, en línea con ideas e intuiciones de Fernando Chueca respecto al sustrato «místico» de la realeza de Felipe II, es que esta escenificación de la dualidad regia viene conscientemente amplificada de mano del Rey Prudente. No extraña el interés, el mimo con el que cuida a la antigua Real Capilla de sus antepasados Trastámara. En 1562, siendo capellán mayor Gaspar de Zúñiga y Avellaneda, entonces arzobispo de Santiago, se redactan los Estatutos de la misma que prevén probanzas de limpieza de sangre para sus miembros. ${ }^{77}$ Más adelante, al sucederse en muy poco tiempo las muertes del capellán mayor titular, Juan de Liermo Hermosa, también arzobispo de Santiago, que fallece el 8 de enero de 1584, y de Luis Manrique de Lara, capellán mayor de ejercicio y limosnero mayor, muerto el 14 de diciembre de 1583, Felipe II ve la oportunidad de unir definitivamente ambas dignidades en el sucesor designado de Manrique, García de Loaysa, quien de hecho pasará a ejercerlas conjuntamente desde primero de octubre de $1584 .^{78}$ Se activaba así una bula papal concedida en 1569 a solicitud del monarca, aunque quepa hacer la salvedad que la unión de facto de ambas dignidades ya se constata y documenta durante el ejercicio de Manrique. ${ }^{79}$ En cualquier caso, la previsión de unir a la capellanía mayor «de ejercicio» la limosnería mayor obedecía a una clara voluntad de reforzar la independencia jurisdiccional de la Real Capilla respecto de los arzobispos de Santiago, titulares desde antiguo de la capellanía mayor de los reyes de Castilla y León. ${ }^{80}$ En 1590 se instala en el altar la copia de mano de Michiel Coxcie de la Adoración del Cordero Místico de Jan van Eyck, ${ }^{81}$ hecho harto significativo pues precede por muy poco a la bula pontificia de 3 de abril de 1591 por la que se permite reservar el Santísimo Sacramento en la Real Capilla del Alcázar. Aunque la traslación solemne desde la vecina Parroquia de San Juan no se

77. Gaspar De ZúÑIga y Avellaneda, Estatuto formado por el Arzobispo de Santiago... acerca del servicio que deben hacer los capellanes de su Real Capilla (1562), BNM, ms. $14018^{(2)}$.

78. BHAM, ms. M/25, Tercera División de la Dignidad de Limosnero m. ${ }^{\text {or }}$ de S.M.

79. José Ángel Montañés Bermúdez, «Luis Manrique Lara, cura de Riópar y Villapalacios, capellán de Carlos V y limosnero mayor de Felipe II» en II Congreso de Historia de Albacete, Instituto de Estudios Albacetenses «Don Juan Manuel», Albacete, 2002, III, pp. 93-109 (pp. 101-103).

80. Hipólito de Samper y Gordejuela atribuye a «la gran Perspicacia de la Prudentissima Doña Ysabel de Castilla» el reconocimiento de la falta de «Jurisdiccion espiritual, y sagrada» de la Real Capilla, dependiente de prelados y párrocos ajenos. Por Bula de Sixto IV de 1474 se exime de la jurisdicción del ordinario al capellán mayor de ejercicio, capellanes, cantores y mozos de capilla además de a los reyes, personas reales y a los oficiales y ministros de la Casa Real, dándose así un primer paso decisivo en la independencia jurisdiccional de la Real Capilla. BHAM, ms. M/25, art. III, ff. 11v-17r y ms. M/34, parte I, cap. 2, p. 14 .

81. «En el Año 1590. mandò S.M. renovar la Capilla, y en ella poner el Retablo nuevo, cuyo lienzo representaua el tiempo del Cordero, y era copia de aquel famoso Miguel Cokien, sacada del original que pinto el insigne Juan Diest, Inventor de la Pintura al Oleo, para Felipe El Bueno, Duque de Borgoña, quando instituyo su orden del Tuson de Oro en su Capilla Ducal». BHAM, ms. M/25, art. III, f. 28v. 


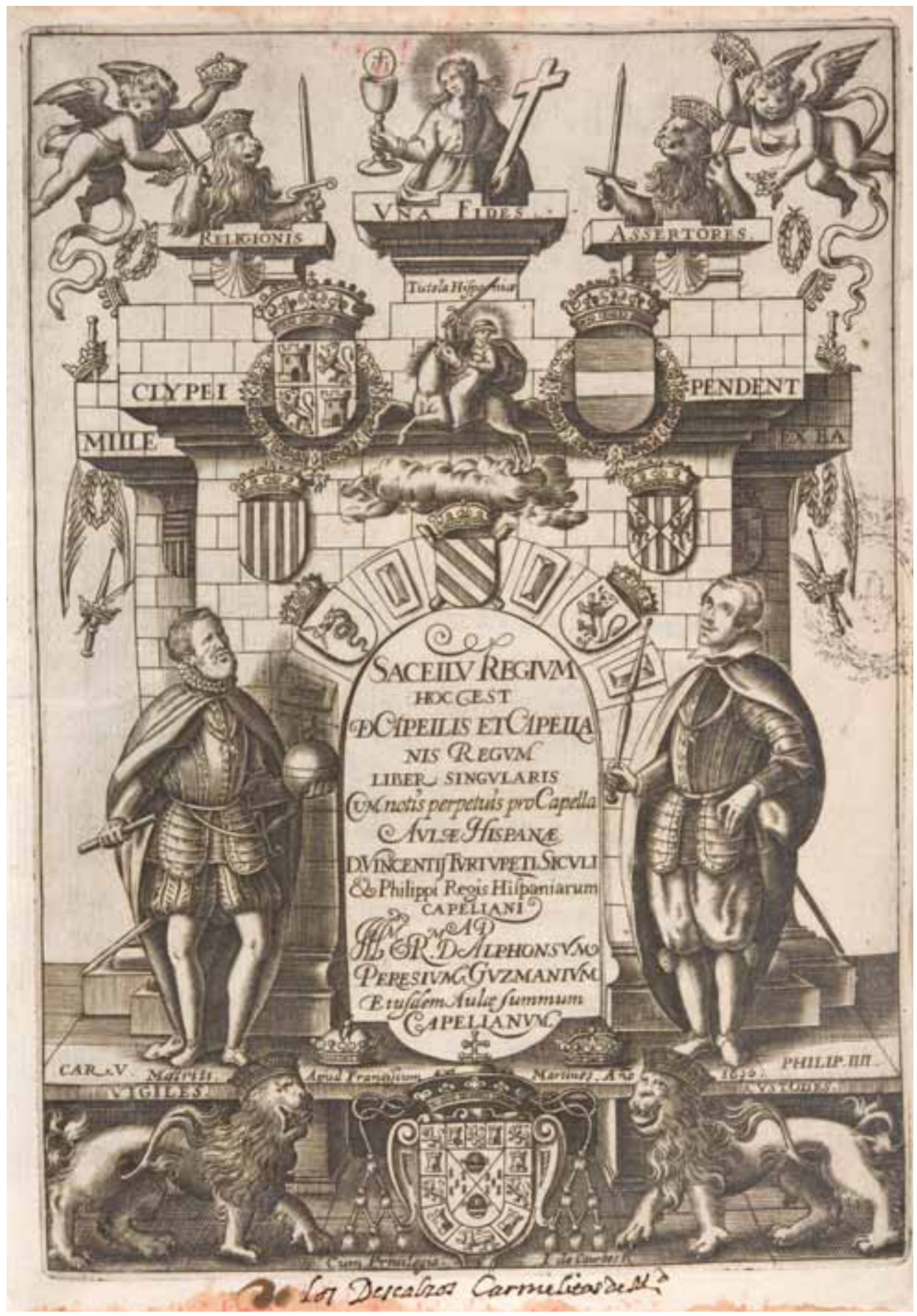

Fig. 9. Jean DE Courbes: Frontispicio de Sacellum Regium hoc est de Capellis et Capellanis Regum cum notis perpetuis pro Capella Aulce Hispanice de V. Tortoretti (1630). Grabado, 134 x 193 mm. Biblioteca Nacional, Madrid, sign. 2/13239 
hace efectiva hasta $1639,{ }^{82}$ en tiempos de Felipe IV, podemos decir que los ingredientes esenciales que convierten a la capilla del Alcázar en un baluarte simbólico y ceremonial de la piedad eucarística de los reyes Habsburgo datan del reinado de su abuelo [Fig. 9].

\section{Teatro de las Dos Majestades}

La potenciación de la Real Capilla como «sede» eucarística sigue una línea de continuidad que, partiendo del reinado de Felipe II, llega hasta el de Carlos II. ${ }^{8_{3}}$ La cuidadosa escenificación del triduo eucarístico de las cuarenta horas es bien representativa de este proceso. Es, creemos, una reafirmación de carácter tanto institucional como simbólico. Si el último de los capellaneslimosneros de Felipe II, Juan de Guzmán, que lo será también de su hijo Felipe III, se convierte en 1602 en el primer capellán mayor de ejercicio en ostentar el patriarcado de las Indias Occidentales, las dignidades permanecerán establemente unidas a partir de 1627 en la persona del capellán mayor Alonso Pérez de Guzmán y de seis de sus sucesores hasta que en 1762, ya en tiempos de Carlos III, el patriarcado de Indias pase a vincularse de manera continuada al vicariato general castrense ${ }^{84}$ No hace falta insistir en la carga simbólica aneja a esta dignidad, más tratándose de la capellanía mayor de un soberano que lo era de «Dos Mundos» y en quien recaía el Patronato Universal de Indias. En el predecesor de Alonso Pérez de Guzmán, Diego de Guzmán, recaerá el arzobispado de Tiro, in pártibus infidélium, añadiendo su aureola de prestigio jerosolimitano y salomónico a la capellanía mayor de un rey católico que era, a su vez, titular del reino latino de Jerusalén. Partiendo, en época de Carlos V, de la hasta cierto punto forzada amalgama de limosneros mayores al estilo de la casa de Borgoña y de capellanes mayores de Castilla, que solo podían serlo como tenientes o sustitutos del arzobispo de Santiago, se llega a lo largo del siglo XVII a una consolidada, prestigiosa e influyente capellanía mayor que es, al decir de Hipólito de Samper, un «compuesto» de cuatro dignidades ya que a la capellanía mayor efectiva del rey católico se unen la limosnería mayor, el patriarcado de las Indias Occidentales y el arzobispado titular de Tiro ${ }^{85}$ Añadamos a esto que en el periodo final de la casa de Austria son nada menos que setenta y ocho los capellanes de honor: cuarenta por Castilla, diez

82. La traslación del Santísimo desde la parroquia de San Juan, que supone la activación de la bula de 3 de abril de 1591, tiene lugar el 10 de marzo de 1639. BHAM, ms. M/25, Indice de los capellanes mayores de los reynos de Castilla, p. 62 y art. III, ff. 29r-30r. Se conmemoró con un libro de exaltación de la ancestral piedad eucarística de los Austrias dedicado al conde-duque de Olivares. Vincenzo TorTORETTI, Maximiliano Socorrido y fragmentos eucharisticos recogidos en la colocacion del Sanctissimo en la Capilla Real del Rei Nuestro Señor Don Filipe IV. El Grande, Francisco Martínez, Madrid, 1639.

83. «Grandes bienes desta morada del Santissimo Sacramento en la Casa Real resultarà a toda su grande Monarquia». Tortoret TI, Maximiliano Socorrido, f. 18v (\$XII).

84. BHAM, ms. $M / 25$, art. IV, $\$ 19$.

85. BHAM, ms. M/25, Quarta Division, f. 1r. 
por Aragón, catorce por Nápoles, Sicilia, Milán y Cerdeña y otros catorce por las cuatro órdenes militares (Santiago, Alcántara, Calatrava y Montesa) y la orden hospitalaria de San Juan de Malta. ${ }^{86}$ En otras palabras, la Capilla Real se configura con los Austrias menores como un reflejo y símbolo de la polisinodia panhispánica, de esa manera de ser reyes, como recuerda Juan Caramuel, realmente presentes en un lugar pero virtualmente en una multitud casi inagotable de reinos y señoríos. ${ }^{87}$

Lo señalado con anterioridad permite entender mejor hasta que punto la «cortina», como espacio privativo de la real majestad en su Real Capilla, participa de ese proceso de magnificación simbólica y política que transforma radicalmente, a lo largo de dos siglos, la itinerante capilla real castellana de los Trastámara en un estable edificio ritual y jurisdiccional de carácter y repercusión internacionales. Dentro de ese contexto, el uso continuado de la «cortina» borgoñona en la España de los siglos XVI y XVII va estrechamente ligado a la potenciación de una funcionalidad implícita, tan evidente por otro lado, de la misma: la de envolver al rey en un aura de aislamiento reverencial. En un estudio ya clásico, Otto Treitinger identificó en el incremento del número de cortinas en el ceremonial imperial bizantino un síntoma claro de la voluntad de distanciar y elevar al emperador, de la que podría describirse como una Absonderung ritualizada y escenificada ${ }^{88}$ Teniendo en cuenta las probables raíces (o afinidades) bizantinas de la práctica ceremonial franco-borgoñona, no ha de extrañar que la «cortina» funcione de manera tan efectiva a la hora de potenciar un registro de distanciamiento y elevación cuasi sacralizantes. Los capellanes regios no dudan en hablar de ese «abismo incomprehensible» que encierra la persona regia: ${ }^{89}$ palabras que han de interpretarse en un sentido jurídico y ontológico, en línea con la bicorporeidad regia de la que escribe Kantorowicz. La real persona es un «abismo» en la medida en que en ella se dan cita la majestas y la humanitas, la perennitas dinástica y la mortalitas individual. La ocultación, si procede hablar de la misma, no tiene nada que ver, como pretendía la princesa de los Ursinos, con una «fantaisie» que nos prive del gentil espectáculo de un rey joven y apuesto. ¿Sugería tal vez la noble francesa que sí era adecuada para monarcas ancianos o, en una alusión apenas velada a Carlos II, poco agraciados?

La narración de las solemnidades capitulares del Toisón de Oro correspondientes a 1593, llevadas a cabo en el Alcázar madrileño, ponen de

86. de Samper y Gordejuela, Sagrada Defensa, art. ini, núm. 7, p. 39. La propia Real Capilla viene consiguientemente definida como un «agregado, ô compuesto de tantas Capillas soberanas». BHAM, ms. M-23, f. $13 \mathrm{v}$.

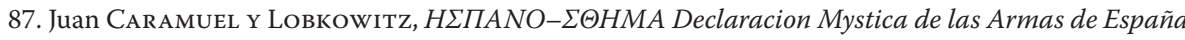
invictamente belicosas, Lucas de Meerbeeck, Bruselas, 1636, cap. XI, pens. II, pp. 191-194.

88. Otto Treitinger, Die oströmische Kaiser- und Reichsidee nach ihrer Gestaltung im höfischen Zeremoniell. Vom oströmischen Staats- und Reichsgedanken, Hermann Gentner Verlag, Darmstadt, 1956, pp. 55-56 y 113-120 (public. orig., Frommann, Jena, 1938).

89. «Y aunque la Magestad es un Abismo incomprehensible, que solo se puede reconocer por los efectos, y no por las causas». De Samper y Gordejuela, Sagrada Defensa, art. IV, p. 49 (\$12). 
manifiesto hasta que punto la «cortina» no era ni pretendía ser un mecanismo de ocultación. ${ }^{90}$ En esa ocasión sustituyó a su padre indispuesto un príncipe Felipe quinceañero que «se metió abaxo de su cortina abierta toda, que era de tela de brocado muy rica, y lo mesmo el sitial y almohadas que tenía delante». Como ocurría con la celebración del día de Santiago El Mayor, ${ }^{91}$ los soberanos asistían a vísperas y misa solemne el día de San Andrés «a cortina abierta», significándose así el carácter palmariamente público de unas solemnidades en las que el rey, o su hijo en representación suya, confraternizaba con los demás caballeros como primus inter pares en su calidad de Gran Maestre del Toisón (o, en lo que respecta a la ceremonia jacobea, de las cuatro órdenes militares). Sin duda preocupado por el buen desarrollo de las ceremonias capitulares que presidía por primera vez su hijo y heredero, Felipe II tomó asiento en el cancel a los pies de la capilla «de manera que no le echavan de veer, y él lo veía todo». Durante el banquete, que presidió asimismo el príncipe, su padre permanece escondido en la puerta del retrete «abiendo hecho poner en ella una tabla que le llegava hasta los pechos, sobre que se echó mirando por entre el tapiz lo que passava». ${ }^{92}$ No puede quedar más claro: el rey «oculto» propiamente dicho, el que ve sin ser visto y controla y fiscaliza a su corte, no se sirve de la «cortina», nada tiene que ver con la «cortina». Sus instrumentos son si acaso otros: el «cancel» a los pies de la Capilla Real que constituye su verdadero oratorio privado, las celosías altas tras las que puede espiar las sesiones de los diversos consejos en el Alcázar, los balcones y parapetos desde los que asiste incógnito a festejos y ceremonias dentro o fuera de sus residencias, los pasadizos volados que dan acceso privilegiado a clausuras y monasterios o los aposentos regios de El Escorial, estratégicamente conectados a una extensa red de pasos estrechos y escaleras. ${ }^{93}$

La importancia de la «cortina» como singular instrumento ceremonial debe curiosamente mucho a su modestia material, a su condición de oratorio portátil. A pesar de que en ella se utilizasen tejidos suntuarios,${ }^{94}$ no dejaba de

90. Rafael Domínguez CASAS, «Ceremonia de la Orden del Toisón de Oro (1501-1598)» en El Legado de Borgoña, pp. 361-397 (pp. 389-391).

91. AGP, Real Capilla, 94/1; BHAM, ms. M-31, f. 79r

92. Domínguez Casas, Ceremonia de la Orden, p. 391.

93. Merece la pena por lo tanto insistir en la fundamental diferencia entre cortinas, visillos o cualquier otro medio que permita asistir a un acto sin ser visto y la función mucho más ambigua y compleja de la «Real Cortina». Un caso particular lo constituía el uso de cortinas para que mujeres asociadas al ejercicio del poder siguieran sin mostrarse ceremonias y reuniones a las que no se les permitía el acceso franco en virtud de su sexo, como lo expuso, con referencia a Agripina La Menor, Christiane Kunst («Das Cubiculum des Princeps als Entscheidungsraum») en el coloquio referido en la nota (*). Se dieron situaciones parecidas en el siglo XVII en la capital pontificia con Cristina de Suecia. Véase, por ejemplo: Relacion de la embaxada de obediencia, que diò en Roma a la Sanctidad de Clemente x. en nombre del Catholico Rey de las Españas Carlos Segundo, y de su Serenissima Madre, Tutora, y Gouernadora, El Excelentissimo Señor D. Pedro Antonio Folch de Cardona, olim de Aragon, Duque de Segorbe y de Cardona, ..., Virrey, Lugartheniente, y Capitan General en el Reyno de Napoles, s.n., s.l. [¿Nápoles?], s.d. [1671], pp. 56-57, que narra como al acto de obediencia ante el pontífice el 27 de enero de 1671 en la Sala Regia del Quirinal asiste la exreina «en parte separada con vna çelosia, donde el adorno señalaba la Magestad, q[ue] allì estaba oculta».

94. Véase por ejemplo la descripción de una «cortina» confeccionada con cuatro cortinas de rico brocado. IVDJ, envío $61^{(\mathrm{II})}$, f. $44 \mathrm{v}$. 
ser una estructura sencilla, fácilmente transportable y adaptable en las expertas manos de los oficiales de la furriera. Por ello mismo su uso era generalizable, sin ocasionar gastos superfluos, a todas las iglesias a las que asistía el rey. El mensaje de mayor impacto que a través de ella se transmitía iba unido al hecho evidente de que solo podían utilizarla el monarca y los de su sangre y que a nadie era permitido, ni siquiera al legado pontificio, situarse bajo dosel en presencia de la misma. $\mathrm{Si}$, por un lado, la «cortina» define un perímetro de protección en torno al rey, permite, por otro lado, que un único seglar, por su condición de monarca, se sitúe en las inmediaciones del altar. Dicho en otros términos, la «cortina» hace patente, en un ámbito sacro, el respeto que los súbditos deben a la «majestad humana» y a su vez marca el respeto que esta debe a la «Majestad Divina». ${ }^{95}$ En consonancia con la caracterización eucarística que la Real Capilla va adquiriendo, esta se convierte en verdadero teatro sacropolítico para el protagonismo de las «Dos Majestades», ${ }^{96}$ divina y humana, encarnadas respectivamente por la Eucaristía en su «cortina de altar» y por el monarca en su «cortina». De la importancia que adquiere la escenificación del vínculo entre ambas majestades no faltan pruebas en el uso mismo de la «cortina». Mientras que el Jueves Santo el rey asiste en ella, el Viernes Santo, sin dejar de comparecer en público, prescinde tanto de ella como de un sitial cubierto. ${ }^{97}$ Se expresa de ese modo el duelo de la majestad humana, postrada para adorar el santo leño de la cruz. Es más, el sábado santo, conmemoración de la muerte de Cristo, el rey sigue como hombre privado los oficios desde el cancel, como señal de luto y corroboración de la imposibilidad de aparecer en «público» sin el sostén de la majestad divina de Cristo. Al día siguiente, sin embargo, Pascua de Resurrección, el rey se restituye públicamente a una «cortina» engalanada de damasco blanco en señal de gozo. ${ }^{98}$ En una misma

95. de Samper y Gordejuela, Sagrada Defensa, art. II, núm. 13, p. 30, compara al rey en su cámara con el Rey de Reyes eucarístico venerado en la Real Capilla.

96. En la España barroca no menudean las referencias a «las dos magestades», humana y divina, en el contexto de una constante exaltación de la catolicidad de la monarquía. Véase, por ejemplo, Fray Luis de SANTA María, osh, Octava sagradamente culta, celebrada de orden del Rey nuestro señor, en la Octava Maravilla, Imprenta Real, Madrid, 1664, serm. 1, \$IV, pp. 186-188.

97. Aclara Matteo Frasso que «el Viernes por el Sagrado misterio que en aquel dia se celebra no usa S.M. Cortina, ni en Lugar de Sitial se pone mas de un Contador sin cubierta, y una silla con Almohada de Terciopelo negro». RAH, ms. 9/708, f. 148r (\$12). Véase asimismo ibid., ff. 138v-139r (\$17), 147v-148r (\$10) y $202 \mathrm{r}(\$ 155)$ y BHAM, ms. M/31, cap. 44 , ff. $84 \mathrm{v}-85 \mathrm{r}$.

98. De nuevo es Matteo Frasso el más explícito: «Para quando SM. ha de venir a la Capilla se prepara la Cortina con la Decencia mas conforme a su Real Grandeza. La materia de que este Aparato se compone es distinta conforme lo pide la Celebridad del Dia. En los Domingos, y dias festivos ordinarios de entre año, las Cortinas son de damasco; las cenefas y almohadas de terciopelo, el arrimadero siempre es el mismo cubierto y tachonado de terciopelo carmesí, solo el terliz es de tafetan doble con unas Puntas de Oro, el color de todo junto carmesi. Pero en el Adviento, y desde la Septuagesima hasta el Domingo de Ramos inclusive (aunque todo es de la materia misma) pero el color morado. En los dias festivos principales de entre año como son las Pasquas de Navidad, de Reyes, y de Resurrección con todo el Tiempo Pasqual, los dias de la Circuncision, del Corpus, y en su Dominica infra octavam, los de Festividades solemnes de nrâ Señora, y el Dia de Juebes Santo, por ser dias de mayor solemnidad se adorna mas rica y preciosam. ${ }^{\text {te }}$. Ponese todo de blanco: la materia es brocado lo mas rico y precioso que pueda ser menos el terliz que es de Tafetan blanco». RAH, ms. 9/708, f. 148r (\$11-12). 
línea, el rey no se sirve de la «cortina» cuando el Santísimo Sacramento está expuesto a la veneración pública, retirándose en esos casos a la privacidad del cancel -dicho de otro modo, cuando la Majestad Divina se hace patente a los fieles, la majestad humana ha de desnudarse de cualquier preeminencia. ${ }^{99}$

Aunque es cierto que la interacción de las «Dos Majestades» no pretendía sacralizar a los reyes sino manifestar su piedad singular y lo exaltado de su misión, la propia mecánica ceremonial se prestaba a potenciales equívocos. No puede sorprender del todo que Francisco Bermúdez de Pedraza en su Historia eucharística o reformación de abusos de 1643 calificase de bárbara la costumbre de sentarse ante la Sagrada Forma expuesta en su «cortina de altar» al mismo tiempo que no se autorizaba a los súbditos a tomar asiento en presencia de su rey pues, según el granadino, se corría el riesgo de reverenciar más a la imagen y representación humanas de la potencia divina que al original mismo. ${ }^{100}$ Las quejas de Bermúdez de Pedraza dan la medida del eco social y de la capacidad persuasiva del ceremonial palatino. Ello explica a su vez el proceso, poco tenido en cuenta, de magnificación simbólica e iconográfica de la «cortina», especialmente acusado entre los Austrias menores. La retratística de los Austrias va frecuentemente acompañada de cortinas que se han tenido por un elemento más del repertorio iconográfico, capaz de connotar la elevación social del retratado. ${ }^{101}$ Es cierto que la presencia de cortinas en retratos no se limita a la realeza, ni tampoco a la alta nobleza, y que su ubicuidad no aconseja lecturas arriesgadas. Hay, sin embargo, numerosos ejemplos de retratos regios en los que la presencia de cortinajes parece aludir a la «cortina» como «ceremonia» distanciadora y prerrogativa regia. Se supone que un magnífico retrato en grisalla de la infanta Isabel Clara Eugenia, obra del pintor toledano Blas de Prado conservada en el Museo de Santa Cruz (fig. 10),

99. En interpretaciones enfáticamente eclesiásticas de la «cortina» se suele, predeciblemente, poner el acento en la devoción y humildad de los monarcas al renunciar a ella, pasando por alto su carácter de regalía. Así, al canónigo de Granada, Francisco Bermúdez de Pedraza, le interesará recalcar que cuando la Eucaristía quedaba patente para su veneración pública en la Real Capilla el rey renunciaba al uso de la «cortina» en señal de humildad: «estando el Rei presente, y de rodillas en el cancel, y no sale en publico a la cortina; por estar mas deuoto, y humilde, en presencia del verdadero Rei inmortal Christo Señor nuestro». Francisco Bermúdez de Pedraza, Historia Eucharistica y reformacion de abusos hechos en presencia de [Christo] Nro. Señor, s.n., s.l.[Granada]. 1643, I, cap. XII, f. 91r. En otro registro bien distinto, al capellán real Manoel Ribeiro le importa más señalar que cuando se sitúa la Eucaristía sobre el altar sería indecente cerrar la cortina frontera pues impediría que el rey la viese. AGP, Real Capilla, 94/1.

100. Bermúdez de Pedraza, Historia Eucharistica, II, cap. XI, f. 87r: «Y seria barbara groseria, no permitir silla a los vassallos en presencia del Rei, por ser Vicario, y retrato de Dios; y ponerla delante del mismo Dios, manifiesto en su Cortina; haziendo mas reuerencia al retrato, que al original». Al mismo autor le llama poderosamente la atención el paralelismo entre la imagen del rey en su "cortina real» y la de la Eucaristía en su «cortina de altar». Ibid., I, cap. XVIII, f. 59v; II, cap. I, ff. 60v y 61v; cap. IX, f. 82v. A acentuar el paralelismo contribuía sin duda la harmonización de los tejidos de ambas «cortinas», eucarística y regia, en función de los tiempos litúrgicos.

101. En el programa del congreso La Corte en Europa: Política y Religión (siglos XVI-XVIII) celebrado en la Universidad Autónoma de Madrid del 13 al 16 de diciembre de 2010 aparece listada entre aquellas comunicaciones no presentadas y remitidas a la publicación de las actas: Mariam VizcAíno VillanUEVA, «El Ceremonial de Cortina de la Capilla Real y su influencia en el retrato de Corte» (en prensa). Agradezco a Víctor Mínguez esta referencia que espero consultar cuando vea la luz y a la que, en todo caso, remito al lector. 


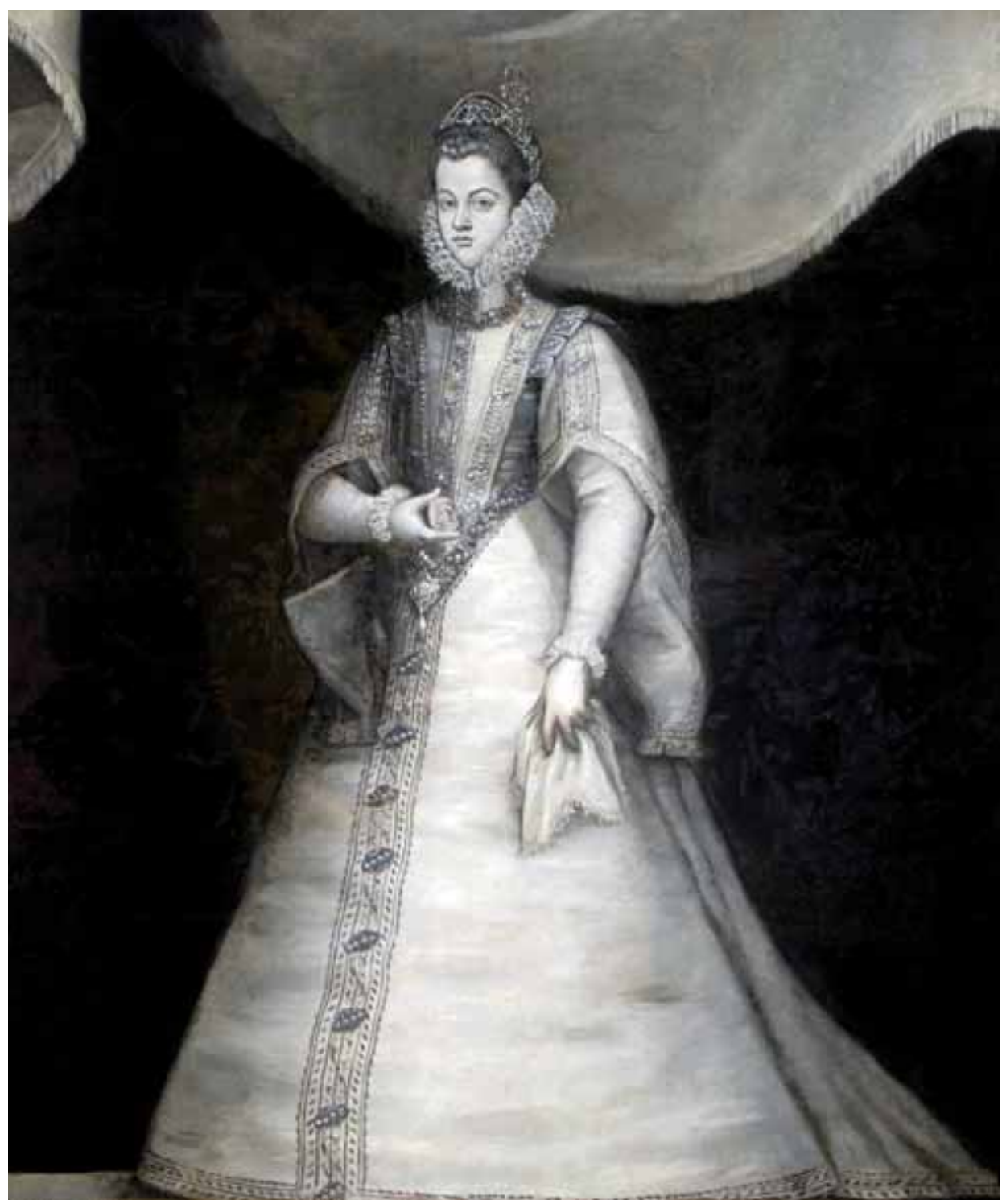

10. Blas de PRAdo: Retrato de la Infanta Isabel Clara Eugenia sosteniendo un camafeo con el retrato de su padre Felipe II (1583). Grisalla al óleo sobre lienzo, 205 x 170 cm. Museo de Santa Cruz de Toledo, núm. inv. 2749 @ Archivo fotográfico del Museo de Santa Cruz de Toledo (๔ Fot. José María Moreno, Toledo)

formaba parte de un conjunto de retratos reales de los que solo se conservaría este y otro en el que aparece la emperatriz María junto a su sobrino Felipe, el futuro Felipe III. ${ }^{102}$ Fueron realizados para adornar alguno de los arcos efímeros

102. L. Ribot García (comisario), Felipe II. Un monarca y su época. Las tierras y los hombres del rey, Sociedad Estatal para la Conmemoración de los Centenarios de Felipe II y Carlos V, Madrid, 1998, p. 208 (cat. núm. 14 por Javier PORTús PÉREZ). 
erigidos con motivo de la solemne traslación de las reliquias de Santa Leocadia a la Ciudad Imperial en 1586. Llama la atención en ambos lienzos conservados la presencia de una cortina parcialmente levantada tras las personas reales, pudiéndose conjeturar que cortinajes similares estuviesen presentes en los restantes lienzos de la serie toledana. De ser así, estaríamos ante una clara asociación de estirpe regia y «cortina» en un contexto de publicidad de la devoción de los Austrias. Sabemos además que Blas de Prado trabajó a partir de originales de Sánchez Coello y no sería extraño que en esta iconografía «cortinada», tan sugestiva de la Absonderung mayestática, hubiese pesado la impronta cortesana filipina en algo más que en los modelos formales.

Incidiendo en esta línea de diferenciación y sublimación, pero ya en el reinado de Carlos II, uno de los emblemas inventados por Juan Baños de Velasco, titulado HIS DVCIBVS IMPERO, refleja fielmente la «Real Cortina» abierta, precedida por un reclinatorio sobre el que descansan la corona y una espada de la Justicia, a la que se enrosca la serpiente de la Prudencia [Fig. 11]. ${ }^{103}$ Aquí, ya en fecha bastante tardía, la «cortina» aparece quintaesenciada como uno de los tres signos fundamentales de la realeza, junto a la espada y la corona. Y ello se enmarca dentro de una «salomonización» consciente y explícitamente propagandística del propio oficio regio en una coyuntura tan crítica como la de la regencia de Mariana de Austria. Más explícita si cabe es la imagen posterior, de 1687, de un Carlos II cual nuevo Salomón entronizado como rey de «Dos Mundos» entre la Justicia y la Prudencia bajo un dosel que recuerda poderosamente a la «Real Cortina» carmesí de uso corriente en la Real Capilla [Fig. 12]. ${ }^{104}$ Alegoría regia que reproduce, en el formato más privado y selecto de unas cartas patentes de nobleza, ideas análogas a las de otras imágenes de mayor circulación. Sirva de ejemplo el conocido grabado de Nicolas Van der Horst que muestra a Felipe IV en un trono de iconografía ostensiblemente salomónica, incluido al inicio del «mausoleo» panegírico que Jean Puget de La Serre dedica en 1634 a la memoria de la tía del rey, Isabel Clara Eugenia, gobernadora de los Países Bajos [Fig. 13] ${ }^{105}$ Esta esmerada estampa, debida a la

103. Juan Baños De Velasco y ACEvedo, L. Anneo Seneca, ilustrado en blasones politicos, y morales, y su impugnador impugnado de si mismo, Mateo de Espinosa y Arteaga, Madrid, 1670, quest. XVIII, pp. 291-304.

104. Titulo de Marques del Arco, à Don Gaspar Marquez de Prado y Bracamonte para si y sus Subçessores, BNM, ms. 20643, f. 5r. Carlos II en su trono con (a la derecha) Gaspar Márquez de Prado y Bracamonte, I Marqués del Arco y (a la izquierda) su padre Alonso Márquez de Prado, del Consejo de Hacienda. El marquesado fue concedido por Real Decreto de 14 de julio de 1687 . Véase, por ejemplo, la cortina carmesí en uso en la capilla real (antes ducal) del palacio de Coudenberg en la que se desposaron Alejandro Farnesio y María de Portugal en 1565: Arlette Smolar Meynart, «Des origines à Charles Quint», en Le palais de Bruxelles. Huit siècles d'art et d'histoire, Crédit communal, Bruselas, 1991, pp. 15-90 (p. 60).

105. Jean Puget de la Serre, Mausolée erigé à la mémoire immortelle de la très-haulte, très-puissante, et très-auguste Princesse Isabelle, Claire, Eugénie, d'Austriche, infante d'Espagne, Jean Pepermans, Bruselas, 1634, ante p. 1. 
inventiva de Cornelis Galle, dota de credenciales salomónicas a la «cortina», ${ }_{106}$ presentándola ingeniosamente como un atributo más de la sabiduría con la que los Austrias ejercen el poder en ellos delegado por Dios. Los ejemplos se podrían multiplicar. De ellos, sin embargo, acaba desprendiéndose un énfasis que roza a veces el pie forzado, especialmente por lo que toca a Carlos II, monarca con cuyas limitadas capacidades casa mal la hiperbólica veste de novus Salomon.

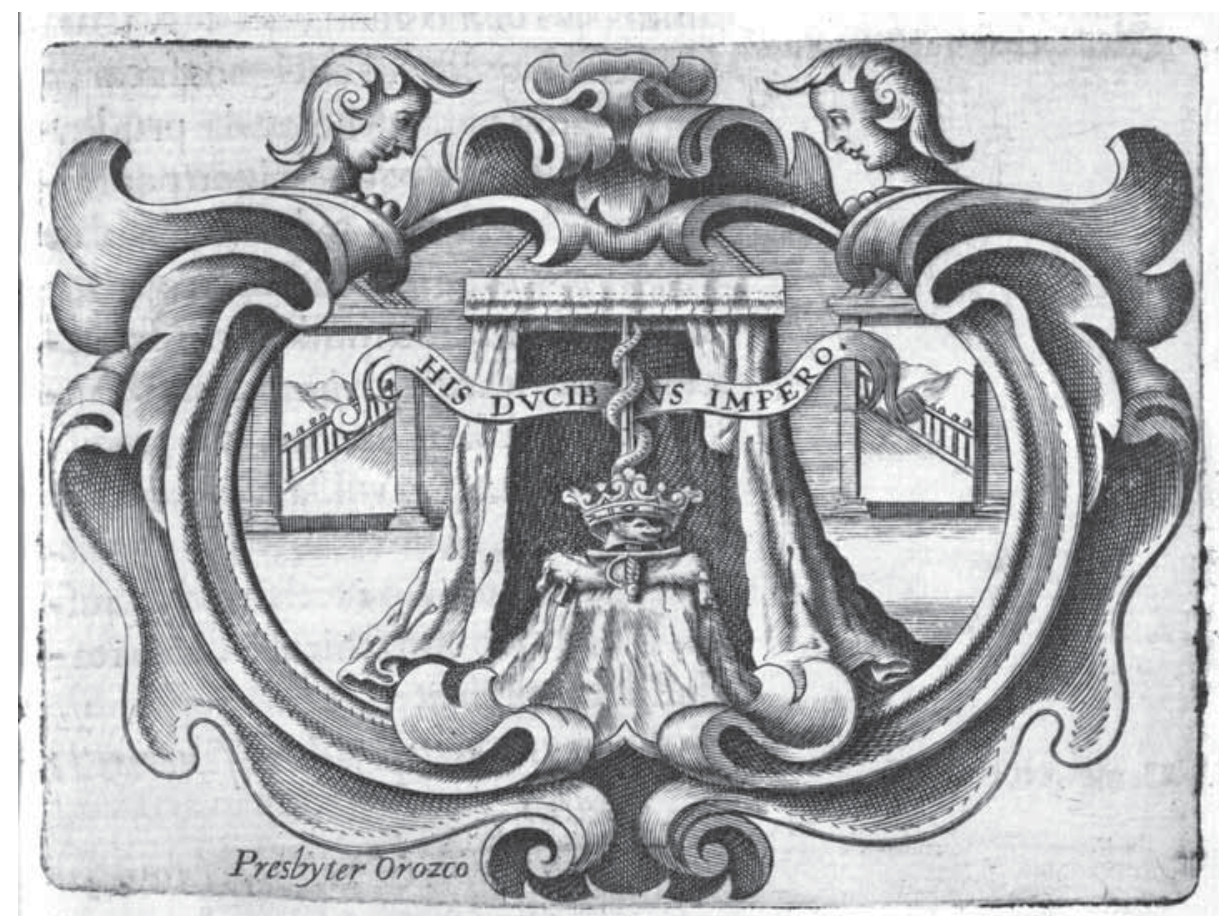

Fig. 11. Marcos Orozco: emblema HIS DVCIBVS IMPERO (1670). Grabado, 134 x 101 mm. Biblioteca Nacional, Madrid, sign. ER/4542, p. 291

106. Al estudiar la pertinencia del uso de los baldaquinos, DE CorTIADA, Decisiones, dec. 287, p. 458 $(\$ 49)$, menciona, no por casualidad, la existencia de un dosel sobre el trono del rey Salomón: «Ubi glossa ait thronum Regis tegmine adornatum esse». Es asimismo bien conocido el interés islámico por el trono de Salomón. Priscilla SoucEK, «Solomon's Throne / Solomon's Bath: Model or Metaphor?», Ars Orientalis, 23 (1993), pp. 109-134. Son frecuentes las imágenes de Felipe IV o de Carlos II sentados en un trono bajo dosel al que se accede por peldaños custodiados por leones, en transparente alusión al mítico trono del rey bíblico. Véanse algunos de los grabados reproducidos en: Elena PÁez Ríos / Elena SAntiago PÁez / Fernando Jesús Bouza Álvarez / Juan Manuel Magariños / Pilar Vinatea Serrano, Los Austrias: Grabados de la Biblioteca Nacional, Julio Ollero Editor / Biblioteca Nacional, Madrid, 1993, passim. 


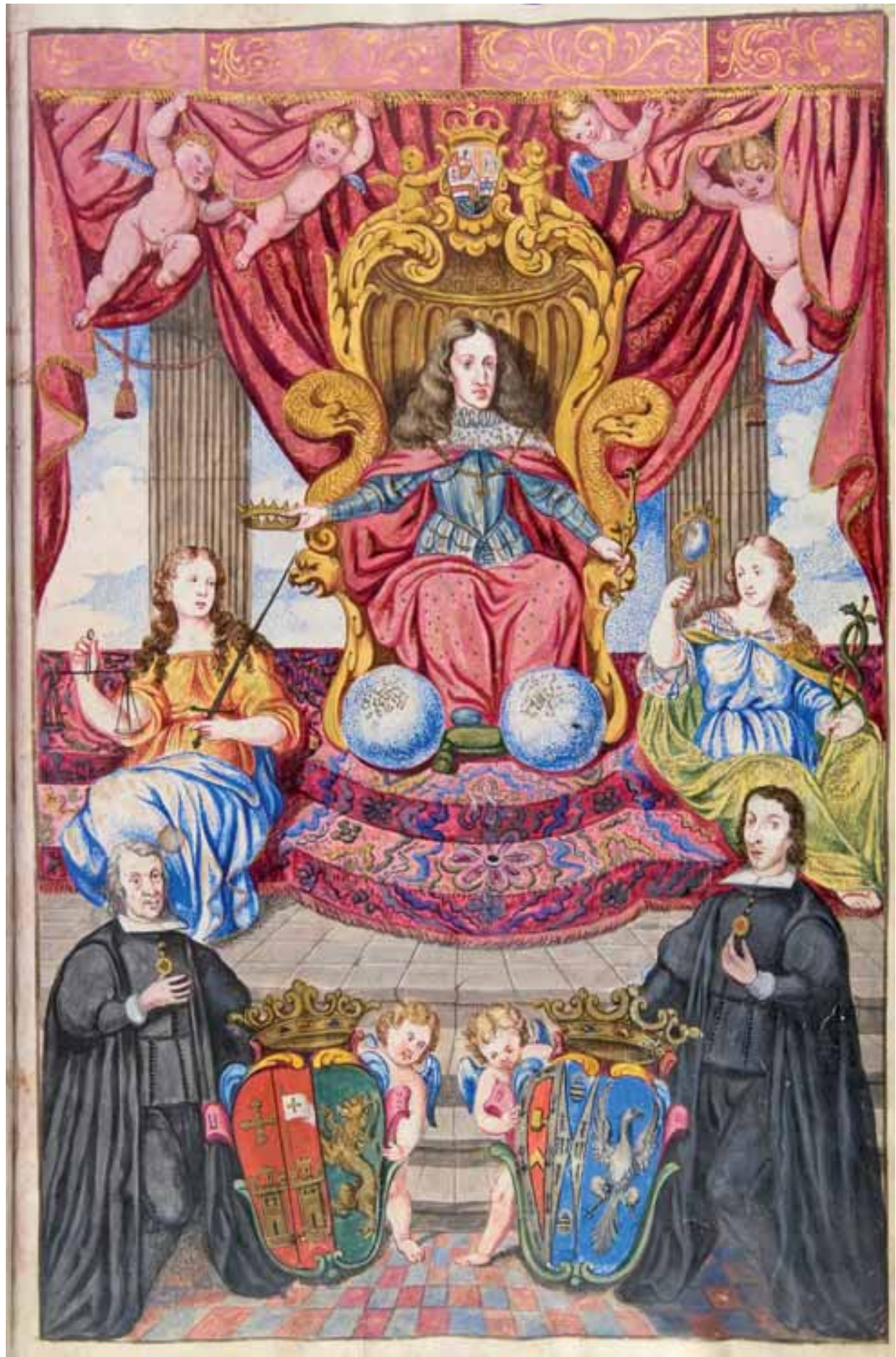

Fig. 12. Anónimo: Carlos II entronizado entre la Justicia y la Prudencia, ilustración del Título de Marqués del Arco Año de 1792 (1687). Pergamino miniado, 198 x 300 mm. Biblioteca Nacional, Madrid, ms. 20643, f. 5r 


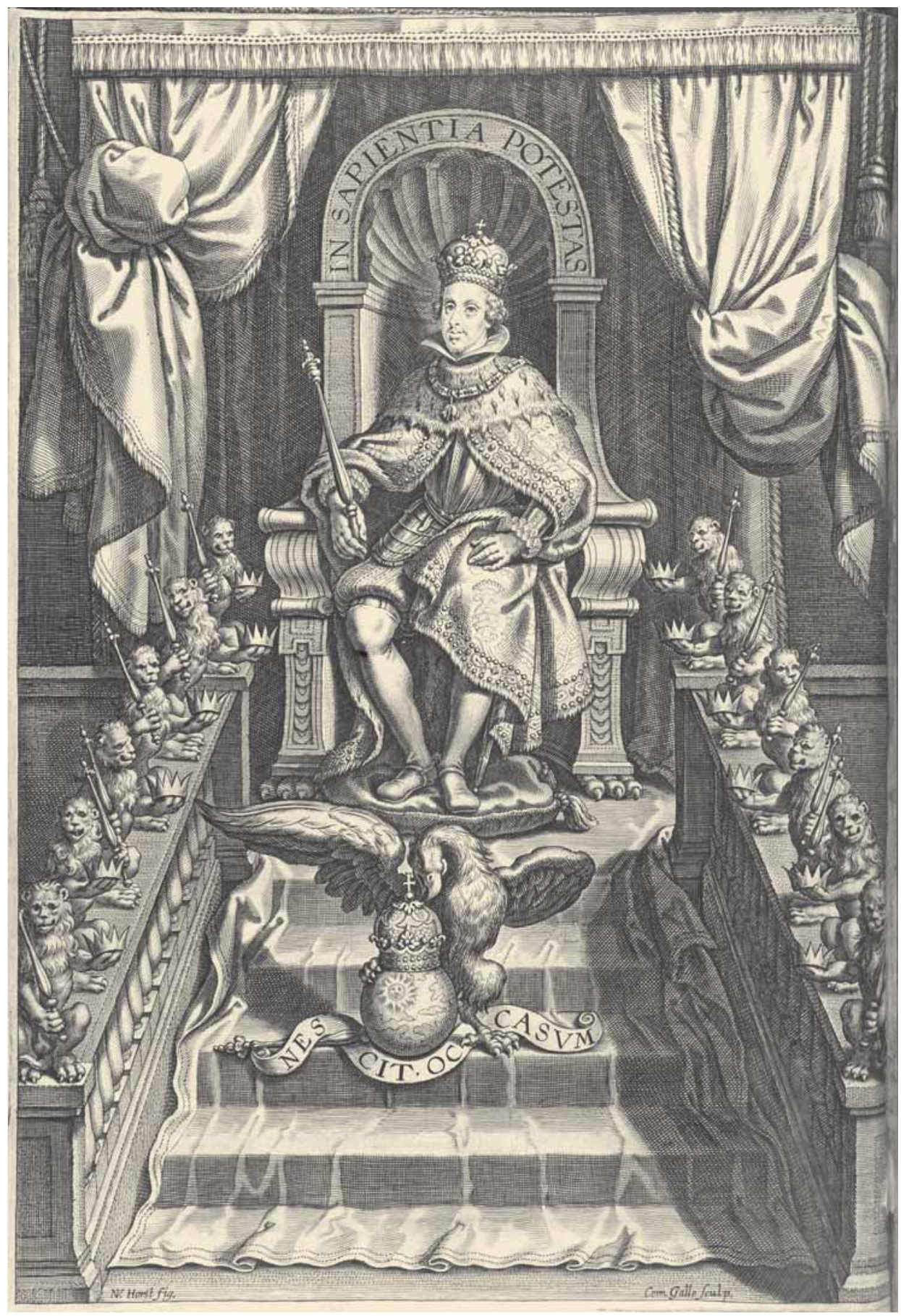

Fig. 13. Cornelis GALLE (invención) y Nicolas VAN DER Horst (grabado): Felipe IV entronizado, ante dedicatoria de Mausolée erigé à la mémoire immortelle de... Isabelle Claire Eugénie d'Austriche de J. Puget de la Serre (1634). Grabado, 274 x 190 mm. Biblioteca Nacional, Madrid, sign. ER/4109. 


\section{EPÍlOGO: EL REY BORBÓN COMULGA EN PÚBLICO «SIN ENJAULARSE»}

Las menguadas facultades de Carlos II dejan al descubierto que un ceremonial que aspire a jugar hábilmente con la distancia, con el distanciamiento, como emblema de la majestad, necesita del anclaje firme de un soberano plenamente capacitado. De no ser así, esos mismos mecanismos ceremoniales acabarían aislándolo, quedando a merced de aquellos cortesanos encargados de su funcionamiento y codificación. Es, claro está, un tema de amplio recorrido histórico. Añadamos que a principios del siglo XvIII, cuando los Borbones se hacen con el trono español, los rituales de velación y desvelo de los soberanos habían caído hacía tiempo en franco desuso en Europa ${ }^{107}$ Como lo demuestran las palabras de la princesa de los Ursinos con las que empezamos, para la mayoría de los europeos carecía por completo de vigencia el concepto de realeza del que se había nutrido la práctica ritual de la «cortina». Para no pocos debía de antojarse abstrusa o anacrónica, incluso a causa de su sobria apariencia casi cúbica y extrañamente refractaria a la evolución de las artes suntuarias. A efectos del rey que acababa de morir, Carlos II, el meticuloso ceremonial hispano-borgoñón había servido, la bien informada Ursinos lo sabía bien, de pantalla protectora. Lo que para Felipe II tuvo carácter afirmativo para el último de los Austrias adolecía más bien de tintes paliativos. ${ }^{108} \mathrm{Si}$ bien es cierto que la «cortina», de cuya ambigüedad ya hemos hablado, no perseguía en sí misma la ocultación del monarca, no puede evitarse la sensación de que, en la medida que contribuía a mantener y legitimar la Absonderung de cuño filipino en un contexto histórico bien distinto, acabó desvirtuándose en un instrumento que disimulaba bajo un aura de intangibilidad a un soberano incapaz. No obstante las inexactitudes, ese convencimiento animaba sin duda las palabras de la Ursinos de 1701 y su enemiga declarada a létiquette de los Austrias.

Pocos meses antes de la carta de la princesa de los Ursinos a Torcy, un informante italiano, verosímilmente romano, narraba con evidente entusiasmo la estupefacción de la corte española ante un rey adolescente de rostro angélico y bellísima melena rubia, ágil y robusto, bailarín diestro y cazador certero y cuya admirable fluidez en la conversación latina dejó al patriarca de Indias literalmente sin palabras. Y, ya en esas primeras jornadas madrileñas del nieto de Luis XIV, entre febrero y marzo de 1701, aun buscando congraciarse a sus súbditos con el uso de la golilla española, el joven monarca «si è comunicato publicamente in Chiesa senza racchiudersi in gabbia, come costumauano Li

107. Con razón John Adamson encuentra paradójico el mantenimiento de la «royal traverse» después de la reforma anglicana. Casi como si se tratase de una transferencia simbólica, la negación de la presencia real de Cristo en la Eucaristía se salda en las ceremonias palatinas de los Tudor (tanto religiosas como seculares) con una magnificación de rituales anteriores a la ruptura con Roma que blindaban a la persona del monarca bajo un aura reverencial. AdAMSON, Tudor and Stuart Court, p. 104.

108. Jorge Fernández-SANTOS OrTIZ-Iribas, «Renovatio regiae pietatis: algunas reflexiones en torno al altar de la Sagrada Forma del Escorial» en: F. J. Campos y Fernández de Sevilla, osA (ed.), El Monasterio del Escorial y la pintura, R.C.U. Escorial-Maㅡ Cristina, San Lorenzo de El Escorial, 2001, pp. 643-674. 
passati Monarchi, che in simile funtione si nascondeuano ne i sacri gabinetti, che però questi spagnoli stanno con La bocca aperta stupidi $\mathrm{p}$ [er] una tal Libertà» ${ }^{109}$. La elección de jaula (gabbia) para describir la "cortina» ${ }^{110}$ no hace sino subrayar la incomprensión que esta provocaba entre diplomáticos y agentes extranjeros a principios del siglo XVIII. El italiano acierta a realzar con maestría y efecto la «connaturale Bizzarria» de un príncipe que no duda en ponerse «con furia Francese la ueste di Cammera», que se lanza sobre un conejo para impedir que se refugie en su madriguera, que trincha su propia carne sin esperar al trinchante y que desayuna pan mojado en vino aguado. La «cortina», como «L'Etichezza della grauità Spagnola» que representa, parecen ser las primeras víctimas designadas del cambio dinástico y ello en nombre de la naturalidad, de la celebración de la humanidad gloriosa del rey. Unos nuevos presupuestos que obviaban cualquier referencia a la escenificación de la bicorporeidad regia sin la cual el ceremonial de capilla de los Austrias perdía un sustrato latente indispensable.

Una andadura de dos siglos tocaba a su fin brusca y aceleradamente, como si, tras un ciclo de estatismo e introversión asociado a una progresiva falta de estímulos externos, no quedara mejor alternativa que la ruptura y la apertura. Ello pone de manifiesto que aunque, aparentemente, el ceremonial áulico tienda a perpetuarse con facilidad, no deja de ser vulnerable ante cambios de gran calado. Una vulnerabilidad que parece ser mayor cuando la propia perpetuación no era ajena a instrumentalizaciones coyunturales. No debiera sorprender demasiado que las más sonadas protestas de destacados cortesanos españoles tengan por único objeto hacer frente a innovaciones que lesionan los privilegios de la primera nobleza a la que pertenecen. Así, el duque de Arcos elevará memorial a Felipe $\mathrm{V}$ contra la equiparación de grandes de España y pares de Francia y el duque de Medinaceli protagonizará la llamada «revuelta del banquillo» contra la concesión al capitán de las guardias de un asiento en la Real Capilla más cercano al rey que el de los grandes. ${ }^{111}$ En cambio, el que Felipe V comulgue sin «cortina» no en privado sino «en

109. Cristoforo Vettori (?), Lettra di Raguaglio p [er] L'arriuo nella Città di Alcalà 6 Leghe Lontana da Madrid del Sigr Duca d’Angiò eletto Rè di Spagna col nome di Filippo V (Madrid, 18 de febrero de 1701) / Relation del primo Ingresso in Madrid del Sig. ${ }^{r}$ Duca d'Angiò eletto Rè di Spagna col Nome di Filippo V con una esatta notitia delle sue operationi (Madrid, 3 de Marzo 1701), BAV, ms. Urb. lat. 1705, ff. 178r-182v.

110. Elección no exenta de carga irónica como lo demuestra el que, poco más abajo, se vuelva a utilizar gabbia para burlarse inmisericordemente de las proezas cinegéticas del difunto Carlos II: «[...] doue andauano si piantaua una gabbia, ò per dir meglio un Padiglione, come una Trabacca da Letto, e quiui staua in Clausura il Rè, sinche gli fusse presentato qualche Colombo, ò altro Vccello Siluestre, che teneuano Legato con spago, e La M. ${ }^{\text {tà }}$ Sua con una Carubina Li sbranaua, tornandosene allhora trionfante in Madrid con La preda inalborata». Ibid., ff. 178v-179r.

111. Luis Salazar de Castro, Memorial sobre tratamientos de los Duques Pares de Francia y los Grandes de España (1701), ms, 10991. José De la SERna, Papel que el s. ${ }^{r}$ D. ${ }^{n}$ Joseph de la Serna del Consejo de Castilla escriviò a instancia del Duque de Medinaceli con motivo de haverse puesto en la Capilla el Banco para sentarse el Capitan de Guardias, y preceder al Banco de Grandes (c. 1706), BNM, ms. 11007, ff. 111r-121r. Véase Luis María García-Badell Arias, «Felipe V, la Nobleza Española y el Consejo de Castilla. La Explicación jurídica e histórica de la consulta que hizo el Real Consejo de Castilla, atribuida a Macanaz», Cuadernos de Historia del Derecho, 12 (2005), pp. 125-149 (p. 136). 
público», algo que contravenía el espíritu y la letra del ceremonial palatino de los Austrias en un aspecto neurálgico del mismo, no genera oposición significativa por más que desconcierte. En la rapidez con la que se resquebraja el protocolo de los Habsburgo a partir de 1701 quizás no debiéramos leer solo un reflejo de la efectividad de la estrategia francesa que pone en práctica la princesa de los Ursinos, sino también una invitación a plantearse la posibilidad de desplazamientos anteriores, a lo largo del siglo XvII, del centro de gravedad de esa añosa «gravedad española» que apenas si supo oponer resistencia a los nuevos tiempos.

\section{Abreviaturas}

AGP Archivo General de Palacio, Madrid.

AGS Archivo General de Simancas, Simancas (Valladolid).

BAV Biblioteca Apostólica Vaticana, Ciudad del Vaticano.

BHAM Biblioteca Histórica del Ayuntamiento, Madrid.

BNM Biblioteca Nacional, Madrid.

IVDJ Instituto de Valencia de Don Juan, Madrid.

RAH Real Academia de la Historia, Madrid. 